\title{
16. TRACE ELEMENT GEOCHEMICAL HISTORY OF LATE MESOZOIC SEDIMENTATION IN THE SOUTHWEST ATLANTIC, FALKLAND PLATEAU, SITE 511 ${ }^{1}$
}

\author{
I. M. Varentsov, Geological Institute of the U.S.S.R. Academy of Sciences, Moscow
}

\begin{abstract}
The distribution of paragenetic assemblages of trace and rare elements, as revealed by factor analysis (R-mode, Q-mode), the ratios of elements to $\mathrm{Zr}$ and the interpretation of these data in the context of the known mineralogy, lithology, and geology of the region, provide the bases for the outline of the geochemical history of sedimentation in the study area that forms the subject of this chapter. Two stages may be discerned.

1. Late-Middle Jurassic-Early Cretaceous (160-106? Ma). The sediments that accumulated in relatively shallow water (shelf) were predominantly clay, with dispersed sapropelic organic matter, plant fragments, pyrite, admixtures of acid-medium volcanic glass, and epigenetic crystals of gypsum. The bottom water layers of the basin are notably stagnant. The sediments are characterized by higher amounts of $\mathrm{V}, \mathrm{Zn}, \mathrm{Cu}, \mathrm{Cr}, \mathrm{Rb}$, and $\mathrm{Be}$ associated with organic matter. Lower Cretaceous sediments, separated from those of the Upper Jurassic by a hiatus, accumulated in a deepened and enlarging basin. These Lower Cretaceous deposits are chemically similar to those of the Upper Jurassic, but contain diagenetic concentrations of $\mathrm{Zn}, \mathrm{Ni}$, and $\mathrm{La}$.

2. Early-middle Albian (Unit 5)-middle Maestrichtian (106?-66.6 Ma). The prevailing regime was that of an open ocean basin that tended to expand and deepen.

During the second half of the early-middle Albian, the biogenic components $\mathrm{Ba}, \mathrm{Sr}$, and $\mathrm{CaCO}_{3}$ accumulated. By the end of this interval, $\mathrm{Ti} / \mathrm{Zr}$ values had increased. In conjunction data on mineral composition, they testify to an outburst of basaltoid volcanism related to tectonic activity before an erosional hiatus (late Albian-Cenomanian).

At the end of the Cenomanian-Turonian, residual deposits of predominantly clay sediments with relatively high amounts of $\mathrm{Ti}$ and $\mathrm{Zr}$ and associated rare alkalis $(\mathrm{Li}, \mathrm{Rb})$ accumulated.

Clay sediments deposited during the Coniacian-Santonian were characterized by higher concentrations of $\mathrm{Ti}, \mathrm{Zr}$, $\mathrm{Li}$, and $\mathrm{Rb}$, by diagenetic carbonate phases of $\mathrm{Ni}, \mathrm{Zn}$, and $\mathrm{La}$, and by sulphides and $\mathrm{Fe}$-oxides with an admixture of $\mathrm{Ni}$ and $\mathrm{Co}$. The latter half of the interval saw the deposition of fine basaltoid volcanoclastic material, diagenetically altered by zeolitization and carbonatization and enriched with $\mathrm{Sc}, \mathrm{Pb}, \mathrm{Ti}, \mathrm{Sr}, \mathrm{Ba}, \mathrm{Y}$, and $\mathrm{Yb}$. Sediments with a similar chemistry accumulated in the Campanian-middle Maestrichtian.

Strong current activity preceding a global hiatus at the Mesozoic/Cenozoic boundary is reflected in both lower sedimentation rates and the presence of higher residual concentrations of $\mathrm{Ti}, \mathrm{Zr}, \mathrm{Ba}, \mathrm{Sr}$, and other elements studied in this chapter.
\end{abstract}

\section{INTRODUCTION}

The upper Mesozoic section penetrated at DSDP Site 511 in the basin province of the Falkland Plateau is crucial for studying the paleogeographical and sedimentary development of the Southwest Atlantic Ocean. Data on the lithology of Middle-Upper Jurassic and Cretaceous sediments in this region are rather fragmentary; they are drawn mostly from Site 330, DSDP Leg 36, situated $10 \mathrm{~km}$ north of Site 511, and no information on the geochemistry is available (Barker, Dalziel, et al., 1977; Ludwig, Krasheninnikov, et al., 1980; Thompson, 1977).

The objective of this chapter is to study the late Mesozoic geochemical history of sedimentation in the Southwest Atlantic in the context of data on oceanic circulation, the climatic evolution of the Antarctic and the Southern Ocean, and the general process of sediment accumulation. The processes of sedimentation and postsedimentary transformations are assumed to have been registered in the chemical and mineral compositions of the sediments. Of special interest are changes in the chemical parameters of sedimentation for the major geochronological subdivisions and the nature of the fac-

\footnotetext{
${ }^{1}$ Ludwig, W. J., Krasheninnikov, v. A., et al., Init. Repts. DSDP, 71: Washington (U.S. Govt. Printing Office).
}

tors controlling them during the Late Jurassic and Cretaceous.

\section{MATERIALS AND METHODS}

This study of the chemical and mineral composition and the lithological characteristics of late Mesozoic deposits penetrated at DSDP Site 511 was carried out at the Geological Institute of the U.S.S.R. Academy of Sciences. Determination of trace elements was carried out at the chemical laboratory of the All-Union Institute of Mineral Resources of the U.S.S.R. Ministry of Geology (M. A. Ritt, laboratory head) using emission spectroscopy and the international standards. Group determinations were made for $\mathrm{Se}, \mathrm{Pb}, \mathrm{Nb}, \mathrm{Ga}, \mathrm{Mo}, \mathrm{V}, \mathrm{Cu}, \mathrm{Zn}$, $\mathrm{Ti}, \mathrm{Co}, \mathrm{Ni}, \mathrm{Zr}, \mathrm{Cr}, \mathrm{Sr}, \mathrm{Ba}, \mathrm{Y}, \mathrm{Yb}$, and $\mathrm{La}$, and elements such as $\mathrm{Li}$, $\mathrm{Rb}, \mathrm{Cs}$, and Be were identified from separate weight portions of samples with relatively high accuracy. $\mathrm{CO}_{2}$ was determined by routine methods and recalculated to $\mathrm{CaCO}_{3}$. Results are given in Table 1. The analytical data were processed by an EC-1022 computer at the mathematical research laboratory, GIN, U.S.S.R. Academy of Sciences (D. A. Kazimirov), using factor analysis (R-mode, Q-mode; Davis, 1973, Harman, 1967). Geochemical interpretations of factor analysis results have been considered, in the context of a similar project, in a previous paper (Varentsov, 1980). The absolute geochronogy is taken from works frequently used in DSDP investigations (Geological Society of London, 1974; Hardenbol and Berggren, 1978; Larson and Hilde, 1975; Van Eysinga, 1975; Van Hante, 1976).

\section{PARAGENETIC ASSEMBLAGES OF ELEMENTS (TABLES 2, 3; FIG. 1)}

The interpretation of paragenetic groups of chemical elements revealed by factor analysis (as just described) enables us to determine the geochemical character of as- 
Table 1. Trace and rare elements and $\mathrm{CO}_{2}$ in upper Mesozoic sediments, Site 511, Falkland Plateau, Southwest Atlantic.

\begin{tabular}{|c|c|c|c|c|c|c|c|c|c|c|c|c|c|c|c|c|c|c|c|c|c|c|c|c|}
\hline \multirow{2}{*}{$\begin{array}{l}\text { Core/Section } \\
\text { (interval in } \mathrm{cm} \text { ) }\end{array}$} & \multirow{2}{*}{$\underset{\text { (wt.\%) }}{\mathrm{CO}_{2}}$} & \multicolumn{19}{|c|}{ Trace Elements (ppm) } & \multicolumn{4}{|c|}{ Rare Elements (ppm) } \\
\hline & & $\mathrm{Sc}$ & $\mathrm{P}$ & $\mathrm{Pb}$ & $\mathrm{Nb}$ & $\mathrm{Ga}$ & Mo & $\mathrm{v}$ & $\mathrm{Cu}$ & $\mathrm{Zn}$ & $\mathrm{Ti}$ & Co & $\mathrm{Ni}$ & $\mathrm{Zr}$ & $\mathrm{Cr}$ & St & $\mathrm{Ba}$ & $\mathrm{Y}$ & $\mathrm{Yb}$ & $\mathrm{La}$ & $\mathrm{Li}$ & $\mathrm{Rb}$ & $\mathrm{Cs}$ & $\mathrm{Be}$ \\
\hline \multicolumn{25}{|c|}{ Campanian-Maestrichtian } \\
\hline $27-2,71-75$ & 0.20 & 10 & 800 & 30 & 15 & 10 & 40 & 100 & 60 & 0 & 1500 & 70 & 150 & 70 & 40 & 200 & 600 & 20 & 2 & 40 & 28 & 82 & $<9.4$ & 1.8 \\
\hline \multicolumn{25}{|c|}{ Coniacian-Santonian } \\
\hline $30-1,50-52$ & 3.83 & 15 & 800 & 15 & 15 & 15 & 1.5 & 100 & 40 & 100 & 1500 & 20 & 30 & 70 & 40 & 200 & 700 & 30 & 2 & so & 28 & 73 & $<9.4$ & 1.4 \\
\hline $38-1,46-50$ & 4.22 & 15 & 1000 & 15 & 10 & is & 6 & 100 & 40 & 100 & 1500 & 20 & 40 & 70 & 40 & 200 & 600 & 30 & 2 & 40 & 32 & 82 & $<9.4$ & 1.4 \\
\hline $38-3,50-54$ & 3.23 & 15 & 800 & is & is & 15 & 3 & 100 & 40 & 100 & 2000 & 20 & 50 & 70 & 40 & 300 & 700 & 30 & 3 & 40 & 37 & 82 & $<9.4$ & 1.8 \\
\hline $39-1,39-43$ & 1.39 & 15 & 1000 & 15 & is & 15 & 3 & 100 & 40 & 100 & 1500 & 20 & 50 & 70 & 40 & 200 & 600 & 30 & 3 & 40 & 37 & 91 & $<9.4$ & 2.5 \\
\hline $39-3,39-43$ & 9.90 & is & 700 & is & 15 & 15 & 3 & 100 & 40 & 0 & 1000 & 20 & 30 & 50 & 40 & 400 & 600 & 30 & 3 & 40 & 32 & 73 & $<9.4$ & 1.4 \\
\hline $39-4,39-43$ & 3.97 & 20 & 1500 & 1000 & 10 & is & 3 & 100 & 40 & 100 & 4000 & 20 & 40 & 80 & 40 & 300 & 700 & 50 & 4 & 50 & 37 & 91 & $<9.4$ & 2.2 \\
\hline $40-2,40-44$ & 5.77 & 20 & 700 & 15 & 10 & 15 & 1.5 & 100 & 40 & 150 & 4000 & 70 & 150 & 60 & 40 & 300 & 700 & 30 & 3 & 50 & 37 & 73 & $<9.4$ & 1.4 \\
\hline $40-3,40-44$ & 19.01 & 15 & 700 & 15 & 10 & 15 & 1 & 40 & 40 & 150 & 700 & 20 & 40 & 50 & 30 & 500 & 1000 & 30 & 3 & 50 & 28 & 55 & $<9.4$ & 1.4 \\
\hline $40-4,40-44$ & 3.34 & is & 800 & 20 & 10 & 20 & 3 & 150 & 60 & 100 & 4000 & 20 & 50 & 100 & 70 & 500 & 700 & 30 & 3 & 0 & 55 & 91 & $<9.4$ & 1.8 \\
\hline $40-5,40-44$ & 0.49 & 15 & 800 & 20 & 10 & 20 & 2 & 100 & 60 & 150 & 2000 & 15 & 40 & 60 & 40 & 300 & 600 & 30 & 3 & 40 & 64 & 100 & $<9.4$ & 2.2 \\
\hline $40-6,20-24$ & 8.44 & 15 & 700 & 20 & 15 & 15 & 2 & 100 & 30 & 0 & 3000 & 20 & 50 & 60 & 40 & 500 & 700 & 30 & 3 & 40 & 60 & 91 & $<9.4$ & 1.8 \\
\hline $41-1,56-60$ & 4.49 & 15 & 700 & 20 & 15 & 20 & 3 & 100 & 30 & 80 & 3000 & 15 & 30 & 70 & 40 & 400 & 700 & 30 & 3 & 50 & 64 & 109 & $<9.4$ & 2.2 \\
\hline $41-2,28-32$ & 5.81 & 20 & 700 & 15 & 10 & 20 & 3 & 100 & 30 & 150 & 3000 & 15 & 40 & 70 & 40 & 400 & 700 & 40 & 3 & 50 & 64 & 100 & $<9.4$ & 1.4 \\
\hline $41-3,59-63$ & 4.26 & 20 & 700 & 15 & 10 & 20 & 3 & 100 & 20 & 100 & 3000 & 15 & 40 & 70 & 40 & 400 & 600 & 30 & 3 & 50 & 87 & 109 & $<9.4$ & 2.2 \\
\hline $42-1,116-120$ & 2.96 & 20 & 700 & 15 & 10 & 20 & 4 & 100 & 40 & 150 & 3000 & 20 & 60 & 100 & 50 & 300 & 300 & 30 & 3 & 50 & 74 & 109 & $<9.4$ & 1.8 \\
\hline $42-2,116-120$ & 5.16 & 15 & 700 & 20 & 10 & 20 & 1.5 & 100 & 40 & 0 & 3000 & 20 & 40 & 100 & 50 & 300 & 300 & 30 & 3 & so & 60 & 91 & $<9.4$ & 1.8 \\
\hline $42-3,116-120$ & 5.48 & 15 & 700 & 20 & 10 & 20 & 1.5 & 100 & 40 & 100 & 2000 & 15 & 30 & 70 & 40 & 300 & 300 & 30 & 3 & 50 & 55 & 91 & $<9.4$ & 1.4 \\
\hline $42-4,116-120$ & 3.99 & 15 & 800 & 15 & 15 & 20 & 3 & 100 & 40 & 80 & 3000 & is & 30 & 100 & 40 & 150 & 200 & 30 & 3 & 50 & 51 & 109 & $<9.4$ & 1.4 \\
\hline $42-5,31-33$ & 7.41 & 15 & 800 & 15 & 15 & 20 & 3 & 100 & 40 & 0 & 3000 & 15 & 30 & 60 & 40 & 300 & 200 & 30 & 3 & 50 & 51 & 91 & $<9.4$ & 1.4 \\
\hline $43-1,43-45$ & 6.06 & 15 & 1000 & 15 & 10 & 15 & 3 & 100 & 30 & 0 & 3000 & 15 & 20 & 100 & 50 & 300 & 200 & 30 & 3 & 40 & 0 & 0 & 0 & 1.4 \\
\hline $43-3,43-45$ & 2.06 & 15 & 1000 & 15 & 10 & 20 & 2 & 100 & 40 & 0 & 4000 & is & 20 & 100 & 40 & 300 & 200 & 30 & 3 & 40 & 41 & 91 & $<9.4$ & 1.8 \\
\hline $44-1,48-50$ & 0.20 & 10 & 700 & 15 & 10 & 20 & 3 & 100 & 40 & 100 & 2000 & 100 & 100 & 70 & 40 & 70 & 150 & 15 & 2 & 0 & 32 & 109 & $<9.4$ & 2.2 \\
\hline $47-2,48-50$ & 1.93 & 15 & 1000 & 20 & 15 & 20 & 2 & 100 & 50 & 100 & 3000 & 20 & 40 & 150 & 50 & 300 & 1000 & 30 & 3 & 40 & 37 & 82 & $<9.4$ & 2.2 \\
\hline $47-3,48-50$ & 2.13 & 15 & 1000 & 20 & 15 & 20 & 3 & 100 & 40 & 100 & 3000 & 15 & 40 & 150 & 50 & 300 & 1000 & 30 & 3 & 40 & 32 & 91 & $<9.4$ & 1.8 \\
\hline $47-4,48-50$ & 6.06 & 15 & 1000 & 10 & 15 & 20 & 3 & 100 & 40 & 70 & 3000 & 15 & 40 & 150 & 50 & 300 & 400 & 30 & 3 & 40 & 32 & 91 & $<9.4$ & 1.4 \\
\hline $47-5,48-50$ & 8.50 & 20 & 800 & 20 & 15 & 20 & 2 & 100 & 50 & 0 & 3000 & 20 & 50 & 150 & 50 & 300 & 600 & 30 & 3 & 40 & 37 & 82 & $<9.4$ & 1.4 \\
\hline $47-6,48-50$ & 7.52 & 15 & 800 & 30 & 15 & 20 & 2 & 100 & 70 & 0 & 3000 & 20 & 50 & 150 & 50 & 150 & 500 & 30 & 3 & 40 & $4 !$ & 91 & $<9.4$ & 1.4 \\
\hline \multicolumn{25}{|c|}{ Turonian-upper Cenomanian } \\
\hline $48-3,46-48$ & 0.20 & 20 & 700 & 30 & 15 & 20 & 2 & 100 & 30 & 100 & 3000 & 20 & 50 & 100 & so & 100 & 200 & 20 & 3 & 40 & 60 & 118 & $<9.4$ & 2.2 \\
\hline $49-1,36-38$ & 0.20 & 15 & 800 & 30 & 15 & 15 & 3 & 100 & 60 & 150 & 3000 & 50 & 60 & 100 & 50 & 200 & 200 & 30 & 3 & 40 & 46 & 100 & $<9.4$ & 1.4 \\
\hline $49-2,36-38$ & 0.27 & 15 & 800 & 30 & is & is & 3 & 100 & so & 100 & 3000 & 50 & 60 & 100 & so & 200 & 200 & 30 & 3 & 40 & 0 & 0 & 0 & 1.8 \\
\hline $49-4,36-38$ & 1.46 & 15 & 800 & 30 & is & 15 & 2 & 100 & 40 & 70 & 3000 & 40 & 60 & 100 & 50 & 200 & 1500 & 30 & 3 & 40 & 37 & 109 & $<9.4$ & 1.8 \\
\hline $49-5,36-38$ & 7.85 & is & 700 & 20 & 10 & 15 & 1 & 70 & 100 & 0 & 3000 & 40 & 60 & 100 & 40 & 300 & 5000 & 30 & 3 & 40 & 0 & 0 & 0 & 1.8 \\
\hline $49-6,36-38$ & 10.10 & 15 & 800 & 20 & 10 & 15 & $i$ & 70 & 30 & 0 & 3000 & 40 & 50 & 60 & 40 & 300 & 3000 & 30 & 3 & 40 & 37 & 91 & $<9.4$ & 1.8 \\
\hline Lower-middle Al & & & & & & & & & & & & & & & & & & & & & & & & \\
\hline $50-1,38-40$ & 18.73 & 15 & 700 & 20 & 10 & 10 & 1 & 70 & 60 & 0 & 3000 & 40 & 40 & 70 & 40 & 300 & 4000 & 30 & 3 & 50 & 37 & 64 & $<9.4$ & 1.1 \\
\hline $50-3,38-40$ & 11.72 & is & 700 & 20 & 15 & 15 & 3 & 60 & so & 0 & 3000 & 40 & 40 & 70 & 40 & 500 & 300 & 20 & 3 & 50 & 0 & $\begin{aligned} 0.4 \\
0\end{aligned}$ & 0 & 0 \\
\hline $51-1,62-66$ & 16.38 & 15 & 700 & 20 & 10 & 15 & 1.5 & 60 & 40 & 0 & 3000 & 30 & 30 & 50 & 20 & 300 & 200 & 20 & 3 & 50 & 37 & 64 & $<9.4$ & 1.4 \\
\hline $51-2,62-66$ & 14.81 & is & 700 & 20 & 10 & 15 & 1.5 & 70 & 30 & 70 & 3000 & 50 & 40 & 60 & 40 & 400 & 200 & 20 & 3 & 50 & 46 & 73 & $<9.4$ & 1.4 \\
\hline $51-3,62-66$ & 18.18 & is & 700 & 20 & 10 & is & 1 & 70 & 30 & 0 & 3000 & 40 & 60 & 100 & 40 & 400 & 400 & 30 & 3 & 50 & 46 & 64 & $<9.4$ & 1.1 \\
\hline $51-4,62-66$ & 17.72 & is & 700 & 20 & 10 & 15 & 1.5 & 80 & 30 & 0 & 3000 & 40 & 60 & 150 & 40 & 400 & 1500 & 30 & 3 & 50 & 46 & 73 & $<9.4$ & 1.4 \\
\hline $51-5,62-66$ & 13.23 & is & 700 & 20 & 10 & is & 1.5 & 70 & 30 & 70 & 3000 & 30 & 60 & 150 & 40 & 400 & 400 & 30 & 3 & 50 & 41 & 82 & $<9.4$ & 1.8 \\
\hline $51-6,62-66$ & 17.83 & is & 800 & 15 & 10 & 15 & 1.5 & 60 & 30 & 0 & 2000 & 40 & 40 & 150 & 30 & 300 & 1500 & 30 & 3 & 40 & 41 & 55 & $<9.4$ & 1.1 \\
\hline $52-1,62-66$ & 9.64 & is & 800 & is & 10 & is & 1.5 & 60 & 30 & 70 & 2000 & 40 & 50 & iso & 30 & 300 & 2000 & 30 & 3 & 0 & 46 & 91 & 9.4 & 1.4 \\
\hline $52-3,62-66$ & 11.67 & is & 800 & 20 & 10 & is & 1.5 & 70 & 30 & 0 & 2000 & 50 & 60 & 150 & 30 & 300 & 1000 & 30 & 3 & 40 & 51 & 73 & $<9.4$ & 1.4 \\
\hline $52-5,62-66$ & 0.90 & 10 & 700 & 15 & 10 & 15 & 1 & 300 & 20 & 100 & 1000 & $\begin{array}{l}30 \\
150\end{array}$ & $\begin{array}{r}60 \\
100\end{array}$ & 70 & $\begin{array}{l}30 \\
15\end{array}$ & $\begin{array}{l}300 \\
150\end{array}$ & 400 & $\begin{array}{l}30 \\
10\end{array}$ & 2 & 40 & $\begin{array}{l}51 \\
83\end{array}$ & $\begin{array}{r}13 \\
9\end{array}$ & $\begin{array}{l}<9.4 \\
<9.4\end{array}$ & $\begin{array}{r}1.4 \\
<0.9\end{array}$ \\
\hline $52-6,62-66$ & 11.89 & 15 & 800 & 20 & 15 & 15 & 2 & 30 & 30 & 100 & 1500 & $\begin{array}{l}150 \\
60\end{array}$ & 60 & 100 & 40 & 300 & 8000 & 30 & $\frac{2}{2}$ & 40 & $\begin{array}{l}83 \\
55\end{array}$ & 55 & $\begin{array}{l}<9.4 \\
<9.4\end{array}$ & $\begin{array}{r}<0.9 \\
1.1\end{array}$ \\
\hline $52-7,16-20$ & 2.74 & 15 & 800 & 20 & 10 & is & 1.5 & so & 30 & 100 & 2000 & $\begin{array}{l}\infty 0 \\
40\end{array}$ & $\begin{array}{l}00 \\
50\end{array}$ & 150 & 30 & 300 & 10,000 & 30 & 3 & 40 & 51 & 64 & $\begin{array}{l}<9.4 \\
<9.4\end{array}$ & $<0.9$ \\
\hline $53-1,76-80$ & $\begin{array}{r}25.60 \\
15.60\end{array}$ & 15 & 800 & 20 & 10 & 15 & 1.5 & 50 & 30 & 0 & 2000 & 40 & 40 & 150 & 30 & 300 & 1000 & 30 & 3 & 40 & 37 & $\begin{array}{l}\text { of } \\
64\end{array}$ & $\begin{array}{l}<9.4 \\
<9.4\end{array}$ & 1.1 \\
\hline $53-2,76-80$ & 7.41 & is & 700 & 20 & 10 & 15 & 1 & 70 & 30 & 0 & 1500 & 70 & $\begin{array}{l}400 \\
100\end{array}$ & 50 & $\begin{array}{l}30 \\
40\end{array}$ & 300 & 800 & 30 & 2 & 40 & 92 & 55 & $<9.4$ & 1.1 \\
\hline $53-3,76-80$ & 14.14 & is & 700 & 20 & is & 10 & 2 & so & 30 & 0 & 2000 & 40 & 40 & 70 & $\begin{array}{l}40 \\
40\end{array}$ & 300 & 1000 & 30 & 3 & 40 & 46 & 64 & $<9.4$ & 1.4 \\
\hline $53-4,76-80$ & 11.44 & is & 700 & 20 & 15 & 15 & 2 & 60 & 40 & 0 & 2000 & 100 & 100 & 70 & 40 & 300 & 600 & 30 & 3 & 0 & 64 & 55 & $\begin{array}{l}<9.4 \\
\end{array}$ & 1.1 \\
\hline $53-6,76-80$ & 17.16 & is & 700 & 10 & 15 & 10 & 1 & 100 & 15 & 0 & 1500 & 100 & 100 & 70 & $\begin{array}{l}40 \\
70\end{array}$ & 300 & 1000 & 20 & 3 & 40 & 55 & 36 & $\begin{array}{l}<9.4 \\
<9.4\end{array}$ & $<0.9$ \\
\hline $54-2,36-40$ & 15.71 & is & 700 & 20 & is & 15 & 1 & 40 & 30 & 0 & 1500 & 40 & 50 & 60 & 30 & 200 & 1500 & 30 & 3 & 50 & 51 & 46 & $<9.4$ & 1.1 \\
\hline
\end{tabular}




\begin{tabular}{|c|c|c|c|c|c|c|c|c|c|c|c|c|c|c|c|c|c|c|c|c|c|c|c|c|}
\hline $54-3,36-40$ & 16.60 & 15 & 700 & 20 & 15 & 15 & 1 & 40 & 30 & 0 & 1500 & 40 & so & 60 & 30 & 200 & 10,000 & 30 & 3 & 50 & 37 & 46 & $<9.4$ & $<0.9$ \\
\hline $54-4,36-40$ & 10.32 & 15 & 700 & 30 & 15 & 15 & 1.5 & 40 & 30 & 0 & 1500 & 30 & 50 & 60 & 30 & 200 & 3000 & 30 & 3 & 50 & 41 & 64 & $<9.4$ & $<0.9$ \\
\hline $54-5,36-40$ & II. 22 & 15 & 700 & 30 & 15 & 15 & 1.5 & so & 40 & 0 & 1500 & 30 & 50 & 60 & 40 & 300 & 1500 & 30 & 3 & 50 & 37 & 64 & $<9.4$ & 1.1 \\
\hline $54-6,36-40$ & 11.11 & 15 & 700 & 30 & 15 & 15 & 1 & 30 & 30 & 0 & 1000 & 20 & 40 & 50 & 40 & 200 & 1500 & 30 & 3 & 50 & 41 & 64 & $<9.4$ & 1.1 \\
\hline $55-1,38-40$ & 15.71 & 15 & 700 & 20 & 15 & 10 & 1.5 & 40 & 30 & 0 & 1500 & 30 & 50 & 60 & 40 & 200 & 800 & 30 & 3 & 50 & 46 & 64 & $<9.4$ & \\
\hline $55-2,38-40$ & 12.00 & 15 & 800 & 30 & 15 & 15 & 3 & 30 & 30 & 100 & 2000 & 30 & 40 & 70 & 40 & 200 & 200 & 30 & 3 & 50 & 55 & 73 & $<9.4$ & 1.4 \\
\hline $55-5,38-40$ & 1.57 & 15 & 1000 & 20 & 15 & 15 & 3 & 70 & 40 & 100 & 2000 & 30 & 40 & 70 & 30 & 150 & 200 & 30 & 3 & 0 & 51 & 82 & $<9.4$ & \\
\hline $55-6,38-40$ & 17.95 & 15 & 800 & 20 & 15 & 15 & 3 & 30 & 30 & 0 & 2000 & 30 & 30 & 70 & 30 & 300 & 200 & 30 & 3 & 0 & 0 & 0 & 0 & 0 \\
\hline $56-2,104-106$ & 6.06 & 15 & 800 & 20 & 10 & 15 & 3 & 40 & 60 & 100 & 1500 & 30 & 60 & 70 & 30 & 150 & 200 & 30 & 3 & 0 & 41 & 64 & $<9.4$ & 1.4 \\
\hline $56-4,99-101$ & 8.62 & 15 & 10,000 & 20 & 15 & 20 & 2 & 70 & 60 & 0 & 1500 & 15 & 150 & 70 & 40 & 300 & 300 & 30 & 3 & 50 & 41 & 36 & $<9.4$ & 1.1 \\
\hline $57-2,28-30$ & 0.22 & 10 & 800 & 15 & 10 & 10 & 2 & 70 & 60 & 200 & 1000 & 30 & 150 & 60 & 30 & 100 & 150 & 30 & 3 & 50 & 55 & 55 & $<9.4$ & 1.8 \\
\hline $57-3,28-30$ & 6.60 & 10 & 1000 & 15 & 15 & 10 & 6 & 70 & 50 & 300 & 1500 & 40 & 300 & 70 & 30 & 100 & 200 & 30 & 3 & 50 & 41 & 46 & $<9.4$ & 1.8 \\
\hline $57-4,28-30$ & 0.85 & 15 & 1000 & 20 & 15 & 15 & 3 & 100 & 70 & 150 & 1500 & 40 & 200 & 70 & 40 & 100 & 200 & 30 & 3 & 50 & 0 & 0 & 0 & 1.8 \\
\hline $57-5,28-30$ & 1.01 & 15 & 1000 & 20 & 15 & 15 & 2 & 100 & 70 & 1000 & 1500 & 40 & 300 & 60 & 40 & 100 & 200 & 30 & 3 & 50 & 51 & 73 & $<9.4$ & 1.8 \\
\hline $57-6,28-30$ & 9.40 & 10 & 1000 & 15 & 15 & 10 & 1.5 & 70 & 40 & 0 & 800 & 40 & 300 & 50 & 40 & 150 & 200 & 30 & 3 & 50 & 37 & 36 & $<9.4$ & 1.4 \\
\hline \multicolumn{25}{|c|}{ Aptian-Barremian } \\
\hline $58-2,40-42$ & 1.21 & 10 & 1000 & 15 & 15 & 15 & 2 & 40 & 20 & 150 & 600 & 0 & 150 & 50 & 10 & 100 & 150 & 15 & 1 & 0 & 37 & 12 & 9.4 & 0.9 \\
\hline $58-3,40-42$ & 1.12 & 15 & 800 & 15 & 10 & 15 & 1.5 & 100 & 50 & 150 & 1500 & 30 & 100 & 50 & 40 & 100 & 300 & 30 & 3 & 40 & 46 & 55 & $<9.4$ & 1.4 \\
\hline $58-4,40-42$ & 0.20 & 15 & 800 & 15 & 15 & 15 & 1.5 & 100 & 40 & 150 & 1500 & 10 & 50 & 60 & 40 & 100 & 300 & 30 & 3 & 50 & 55 & 55 & $<9.4$ & 1.4 \\
\hline $59-1,9-11$ & 15.15 & 15 & 3000 & 15 & 10 & 10 & 30 & 1000 & 150 & 1000 & 1500 & 15 & 100 & 50 & 150 & 500 & 300 & 40 & 4 & 50 & 37 & 36 & $<9.4$ & $<0.9$ \\
\hline $59-2,9-11$ & 2.74 & 15 & 800 & 15 & 10 & 15 & 10 & 200 & 80 & 200 & 1500 & 15 & 60 & 70 & 150 & 100 & 300 & 30 & 3 & 0 & 46 & 82 & $<9.4$ & 2.9 \\
\hline $60-1,144-146$ & 25.36 & 10 & 700 & 7 & 10 & 6 & 30 & 100 & 30 & 0 & 1000 & 0 & 100 & 30 & 40 & 300 & 300 & 20 & 1 & 50 & 9 & 28 & $<9.4$ & $<0.9$ \\
\hline $60-2,144-146$ & 22.89 & 15 & 700 & 7 & 10 & 7 & 30 & 300 & 30 & 500 & 1500 & 0 & 100 & 60 & 70 & 300 & 300 & 20 & 3 & 50 & 28 & 36 & $<9.4$ & $<0.9$ \\
\hline $61-1,57-61$ & 0.20 & 15 & 1000 & 20 & 10 & 15 & 4 & 300 & 40 & 300 & 2000 & 15 & 70 & 100 & 200 & 100 & 400 & 30 & 3 & 50 & 51 & 100 & 9.4 & 1.1 \\
\hline $61-2,57-61$ & 2.67 & 15 & 1000 & 15 & 10 & 15 & 20 & 400 & 40 & 300 & 2000 & 15 & 70 & 100 & 150 & 150 & 400 & 30 & 3 & 0 & 0 & 0 & 0 & 1.8 \\
\hline $61-3,57-61$ & 0.20 & 15 & 1000 & 20 & 10 & 15 & 6 & 300 & 40 & 200 & 2000 & 15 & 70 & 100 & 150 & 100 & 300 & 30 & 3 & 50 & 51 & 109 & 9.4 & 1.8 \\
\hline $61-4,46-50$ & 0.63 & 15 & 1000 & 20 & 10 & 15 & 7 & 400 & 40 & 300 & 3000 & 15 & 80 & 150 & 200 & 150 & 400 & 40 & 4 & 50 & 55 & 109 & 9.4 & 1.8 \\
\hline $61-5,32-34$ & 3.48 & 15 & 1000 & 20 & 10 & 15 & 40 & 400 & 40 & 300 & 3000 & 15 & 80 & 80 & 100 & 150 & 400 & 30 & 4 & 0 & 37 & 100 & $<9.4$ & 1.4 \\
\hline $62-2,50-54$ & 0.20 & 15 & 1000 & 15 & 10 & 15 & 4 & 200 & 50 & 100 & 2000 & 10 & 60 & 70 & 200 & 150 & 400 & 30 & 4 & 50 & 60 & 118 & 9.4 & 1.4 \\
\hline $62-4,116-120$ & 0.20 & 15 & 1000 & 15 & 15 & 15 & 3 & 300 & 50 & 150 & 2000 & 15 & 60 & 100 & 200 & 150 & 400 & 40 & 4 & 40 & 46 & 118 & 9.4 & 2.2 \\
\hline $62-5,36-40$ & 0.20 & 15 & 1000 & 15 & 15 & 15 & 3 & 300 & 30 & 150 & 2000 & $\begin{array}{lll}0 & \end{array}$ & 60 & 100 & 200 & 100 & 400 & 40 & 4 & 40 & 46 & 118 & 9.4 & 2.2 \\
\hline
\end{tabular}

Upper Jurassic

\begin{tabular}{|c|c|c|c|c|c|c|c|c|c|c|c|c|c|c|c|c|c|c|c|c|c|c|c|c|}
\hline $63-1,126-130$ & 0.60 & 15 & 1000 & 30 & 15 & 20 & 40 & 300 & 40 & 300 & 2000 & 20 & 80 & 70 & 60 & 150 & 400 & 30 & 3 & 40 & 37 & 146 & 9.4 & 2.2 \\
\hline $63-2,68-72$ & 0.64 & 15 & 1000 & 20 & 15 & 20 & 40 & 300 & 40 & 150 & 2000 & 20 & 100 & 100 & 100 & 150 & 400 & 30 & 3 & 0 & 41 & 164 & 9.4 & 2.2 \\
\hline $63-3,129-133$ & 3.66 & 15 & 1000 & 20 & 15 & 15 & 30 & 400 & 30 & 600 & 2000 & 15 & 70 & 100 & 100 & 150 & 400 & 40 & 3 & 50 & 37 & 146 & 9.4 & 1.8 \\
\hline $64-1,26-30$ & 1.21 & 15 & 1000 & 20 & 15 & 15 & 40 & 300 & 40 & 600 & 3000 & 15 & 70 & 100 & 100 & 150 & 400 & 40 & 4 & 0 & 37 & 146 & 9.4 & 1.4 \\
\hline $64-2,41-45$ & 1.21 & 15 & 1000 & 15 & 10 & 15 & 6 & 300 & 40 & 150 & 3000 & 15 & 50 & 70 & 100 & 150 & 400 & 30 & 3 & 0 & 46 & 146 & 9.4 & 2.2 \\
\hline $64-3,26-30$ & 1.00 & 15 & 1000 & 20 & 10 & 15 & 3 & 300 & 40 & 600 & 3000 & 15 & 70 & 100 & 100 & 150 & 400 & 30 & 3 & 0 & 37 & 146 & 9.4 & 2.2 .5 \\
\hline $\begin{array}{l}64-4,75-79 \\
64-5\end{array}$ & 1.77 & 15 & 1000 & 20 & 10 & 15 & 3 & 400 & 40 & 700 & 3000 & 15 & 70 & 150 & 100 & 150 & 400 & 30 & 3 & 50 & 37 & 146 & $<9.4$ & 2.5 \\
\hline $\begin{array}{l}64-5,51-55 \\
64-6,12-16\end{array}$ & $\begin{array}{l}1.13 \\
3.76\end{array}$ & ${ }_{15}^{15}$ & $\begin{array}{l}1000 \\
1000\end{array}$ & 20 & 10 & $\begin{array}{l}15 \\
15\end{array}$ & $\begin{array}{l}30 \\
30\end{array}$ & $\begin{array}{l}300 \\
300\end{array}$ & $\begin{array}{l}40 \\
40\end{array}$ & 600 & 3000 & 15 & $\begin{array}{l}70 \\
70\end{array}$ & 70 & 100 & 150 & 400 & 30 & 3 & 50 & 41 & 146 & 9.4 & 2.5 \\
\hline $\begin{array}{l}64-6,12-16 \\
65-152-56\end{array}$ & 3.76 & $\begin{array}{l}15 \\
15\end{array}$ & $\begin{array}{r}1000 \\
800\end{array}$ & ${ }_{15}^{20}$ & $\begin{array}{l}15 \\
15\end{array}$ & 15 & 30 & 300 & 40 & 600 & 3000 & 15 & 70 & 60 & $\begin{array}{l}100 \\
70\end{array}$ & $\begin{array}{l}150 \\
150\end{array}$ & 400 & 30 & 3 & 50 & 32 & 137 & $<9.4$ & $\begin{array}{l}1.8 \\
2.2\end{array}$ \\
\hline $\begin{array}{l}65-1,52-36 \\
65-2,22-26\end{array}$ & $\begin{array}{l}2.00 \\
1.66\end{array}$ & $\begin{array}{l}15 \\
15\end{array}$ & $\begin{array}{l}800 \\
700\end{array}$ & $\begin{array}{l}15 \\
15\end{array}$ & $\begin{array}{l}15 \\
10\end{array}$ & 20 & $\begin{array}{l}30 \\
15\end{array}$ & $\begin{array}{l}2000 \\
300\end{array}$ & $\begin{array}{l}40 \\
50\end{array}$ & 600 & 3000 & 15 & 100 & $\begin{array}{l}100 \\
70\end{array}$ & 700 & $\begin{array}{r}1500 \\
200\end{array}$ & $\begin{array}{l}400 \\
300\end{array}$ & 30 & 3 & $\begin{array}{l}50 \\
40\end{array}$ & 37 & 137 & 18.8 & 2 \\
\hline $\begin{array}{l}65-2,22-26 \\
65-3,63-67\end{array}$ & 1.81 & is & $\begin{array}{l}700 \\
800\end{array}$ & 15 & 15 & 20 & 40 & $\begin{array}{l}300 \\
400\end{array}$ & $\begin{array}{l}50 \\
50\end{array}$ & $\begin{array}{l}600 \\
200\end{array}$ & $\begin{array}{l}1500 \\
1500\end{array}$ & $\begin{array}{l}15 \\
15\end{array}$ & 100 & 70 & 100 & $\begin{array}{r}200 \\
200\end{array}$ & $\begin{array}{l}300 \\
300\end{array}$ & 30 & 3 & $\begin{array}{l}40 \\
50\end{array}$ & 37 & ${ }_{109}^{137}$ & $\begin{array}{r}9.4 \\
-9.4\end{array}$ & 2 \\
\hline $65-5,18-22$ & 4.23 & 15 & 800 & 8 & 15 & 15 & 15 & 400 & 50 & 500 & 1500 & 15 & 100 & 70 & 100 & 200 & 300 & 30 & 3 & 0 & 32 & 118 & $\begin{array}{r}<9.4 \\
9.4\end{array}$ & 2.2 \\
\hline $66-1,34-36$ & 4.34 & 15 & 800 & 10 & 15 & 15 & 60 & 400 & 60 & 400 & 1500 & 15 & 100 & 70 & 100 & 200 & 300 & 30 & 3 & 50 & 37 & 127 & 9.4 & 2 \\
\hline $66-2,30-32$ & 2.23 & 15 & 1000 & 15 & 15 & 20 & 70 & 400 & 60 & 600 & 1500 & 20 & 100 & 70 & 100 & 200 & 300 & 40 & 3 & 50 & 37 & 137 & 9.4 & 2 \\
\hline $66-3,34-36$ & 3.78 & 15 & 700 & 10 & 10 & 15 & 40 & 300 & 50 & 150 & 1500 & 15 & 100 & 60 & 80 & 150 & 200 & 30 & 3 & 0 & 37 & 118 & 9.4 & 2 \\
\hline $66-4,30-32$ & 3.17 & 10 & 800 & 30 & 10 & 15 & 30 & 400 & 50 & 400 & 1500 & 15 & 100 & 60 & 80 & 150 & 200 & 30 & 3 & 0 & 37 & 118 & 9.4 & \\
\hline $66-5,34-36$ & 2.15 & 15 & 800 & 15 & 15 & 15 & 40 & 300 & 60 & 300 & 1500 & 15 & 100 & 60 & 80 & 150 & 200 & 30 & 3 & 0 & 37 & 118 & 9.4 & \\
\hline $66-6,30-32$ & 1.81 & 10 & 700 & 15 & 15 & 15 & 30 & 300 & 40 & 300 & 1500 & 15 & 70 & 60 & 70 & 150 & 200 & 30 & 3 & 0 & 37 & 137 & 9.4 & \\
\hline $67-1,85-87$ & 1.92 & 10 & 700 & 10 & 15 & 15 & 30 & 300 & 40 & 150 & 1500 & 15 & 70 & 50 & 60 & 100 & 200 & 30 & 3 & 0 & 41 & 137 & 9.4 & \\
\hline $67-2,85-87$ & 6.10 & 10 & 700 & 10 & 10 & 15 & 30 & 300 & 40 & 150 & 1500 & 15 & 70 & & 60 & 150 & 200 & 30 & 3 & 50 & 28 & 55 & 9.4 & \\
\hline $67-4,85-87$ & 0.89 & 10 & 800 & 15 & 10 & 15 & 30 & 300 & 40 & 200 & 1500 & 15 & 100 & 50 & 100 & 150 & 300 & 30 & 3 & 50 & 37 & 118 & 9.4 & \\
\hline $67-5,85-87$ & 1.18 & 10 & 800 & 20 & 15 & 15 & 40 & 400 & 40 & 300 & 1500 & 15 & 70 & 70 & 100 & 150 & 300 & 30 & 3 & 0 & 37 & 91 & $<9.4$ & \\
\hline $68-2,65-67$ & 1.11 & 10 & 1000 & 20 & 15 & 20 & 15 & 300 & so & 800 & 1500 & 15 & 70 & 70 & 100 & 150 & 300 & 30 & 3 & 50 & 37 & 137 & 9.4 & \\
\hline $69-2,38-40$ & 0.26 & 10 & 1000 & 20 & 15 & 20 & 7 & 150 & 50 & 150 & 1500 & 15 & 60 & 70 & 100 & 150 & 300 & 30 & 3 & 0 & 41 & 146 & 9.4 & \\
\hline $69-3,38-40$ & 0.26 & 10 & 700 & 10 & 10 & 15 & 3 & 200 & 40 & 100 & 3000 & 10 & 60 & 100 & 100 & 100 & 200 & 20 & 2 & 40 & 46 & 146 & $\begin{array}{r}9.4 \\
<-94 \\
\end{array}$ & 5 \\
\hline $69-5,38-40$ & 0.26 & 15 & 800 & 10 & 10 & 15 & 5 & 300 & 50 & 100 & 3000 & 15 & 70 & 150 & 150 & 150 & 400 & ${ }_{50}^{30}$ & 3 & 40 & 41 & 118 & $<9.4$ & ${ }_{8}^{2}$ \\
\hline $70-1,52-54$ & 0.95 & 15 & 1000 & 15 & 10 & 15 & 10 & 200 & 40 & 100 & 3000 & 15 & 60 & 150 & 100 & 200 & 400 & $\begin{array}{l}50 \\
30\end{array}$ & 5 & $\begin{array}{l}40 \\
30\end{array}$ & 37 & $\begin{array}{l}109 \\
137\end{array}$ & 9.4 & \\
\hline $70-3,52-54$ & 0.22 & 15 & 800 & 8 & 10 & 10 & 4 & 300 & 50 & 100 & 3000 & 10 & 50 & 150 & 100 & 150 & 300 & 30 & 3 & 30 & 46 & 137 & 9.4 & \\
\hline $70-5,52-54$ & 0.20 & 15 & 1000 & 20 & 10 & 20 & 4 & 300 & 70 & 150 & 3000 & 15 & 60 & 150 & 150 & 150 & 400 & 20 & 2 & 40 & 41 & 137 & 9.4 & \\
\hline
\end{tabular}

Note: 0 means "no information." 
Table 2. Factor analyses (R-mode) of trace elements in upper Mesozoic sediments, Site 511, Falkland Plateau, Southwest Atlantic.

\begin{tabular}{|c|c|c|c|c|c|c|}
\hline \multirow[b]{3}{*}{ Component } & \multicolumn{6}{|c|}{ Factor Loading (after rotation) } \\
\hline & \multicolumn{2}{|c|}{$\mathrm{I}$} & \multicolumn{2}{|c|}{ II } & \multicolumn{2}{|c|}{ III } \\
\hline & $\mathrm{IA}(+)$ & $\overline{I B(-)}$ & $\operatorname{IIA}(+)$ & $\overline{\operatorname{IIB}(-)}$ & IIIA(+) & IIIB(-) \\
\hline $\mathrm{Sc}$ & & -0.07 & 0.23 & & 0.57 & \\
\hline $\mathrm{Pb}$ & & -0.13 & 0.13 & & 0.39 & \\
\hline $\mathrm{Nb}$ & & -0.02 & & -0.14 & & -0.02 \\
\hline Ga & 0.18 & & 0.60 & & 0.15 & \\
\hline Mo & 0.75 & & & -0.34 & & -0.06 \\
\hline $\mathrm{v}$ & 0.87 & & & -0.06 & & -0.07 \\
\hline $\mathrm{Cu}$ & 0.51 & & & -0.13 & 0.12 & \\
\hline $\mathrm{Zn}$ & 0.67 & & & -0.50 & & -0.03 \\
\hline $\mathrm{Ti}$ & 0.13 & & 0.64 & & 0.46 & \\
\hline Co & & -0.68 & & -0.02 & & -0.17 \\
\hline $\mathrm{Ni}$ & 0.28 & & & -0.52 & & -0.40 \\
\hline $\mathrm{Zr}$ & 0.09 & & 0.63 & & 0.27 & \\
\hline $\mathrm{Cr}$ & 0.83 & & 0.04 & & 0.16 & \\
\hline $\mathrm{Sr}$ & & -0.52 & 0.02 & & 0.56 & \\
\hline $\mathrm{Ba}$ & & -0.51 & 0.09 & & 0.37 & \\
\hline $\mathrm{Y}$ & 0.35 & & & -0.02 & 0.73 & \\
\hline $\mathrm{Yb}$ & 0.34 & & 0.07 & & 0.68 & \\
\hline $\mathrm{La}$ & 0.04 & & & -0.52 & 0.22 & \\
\hline $\mathrm{Li}$ & & -0.19 & 0.48 & & 0.05 & \\
\hline $\mathrm{Rb}$ & 0.68 & & 0.46 & & 0.29 & \\
\hline $\mathrm{Be}$ & 0.68 & & 0.38 & & & -0.05 \\
\hline $\mathrm{CaCO}_{3}$ & & -0.60 & & -0.40 & 0.43 & \\
\hline Input & & & & & & \\
\hline \multicolumn{7}{|l|}{ Dispersion } \\
\hline$\%$ & 25.57 & & 15.82 & & 9.25 & \\
\hline Cumulative & 25.57 & & 41.39 & & 50.64 & \\
\hline
\end{tabular}

semblages such as compounds or specific forms of the groups of components that have been established by analysis. This determination proceeds by examining the mineral composition of sediments and the parameters of the processes that have the highest probability of yielding the elemental forms that actually occur.

\section{Assemblage IA(+)}

$\mathrm{Ga} \quad(0.18)-\mathrm{Mo}(0.75)-\mathrm{V}(0.87)-\mathrm{Cu}(0.51)-\mathrm{Zn}(0.67) \mathrm{Ni}$ $(0.28)-\mathrm{Cr}(0.83)-\mathrm{Y}(0.35)-\mathrm{Yb}(0.34)-\mathrm{Rb}(0.68)-\mathrm{Be}(0.68)$ Dispersion: $25.57 \%$.

The well-understood association of this cluster of components with certain types of deposits and the peculiarities of its distribution within a section enable us to state that (1) the assemblage is clearly confined to the "black shales" (Unit VI); (2) the average factor scores of the assemblage regularly decrease over time, from the Upper Jurassic (1.15) through the Aptian-Barremian (1.07) to the lower-middle Albian (Unit VI) (0.41). The average content of $\mathrm{C}_{\text {org }}$ (wt. \% Fig. 2) decreases in the same succession: in the Upper Jurassic it is 3.26, in the Aptian-Barremian 3.02, and in the lower-middle Albian (Unit VI) it is 1.10 . Higher up the section $\mathrm{C}_{\text {org }}$ content abruptly decreases (Fig. 2). This assemblage may be related to the humified organic matter that is dispersed throughout the sediments of Unit VI and that is represented particularly by organometallic compounds of $\mathrm{V}, \mathrm{Zn}, \mathrm{Cr}$, and $\mathrm{Cu}$.

$$
\begin{aligned}
& \text { Assemblage } \mathrm{IB}(-) \\
& \mathrm{Pb}(-0.13)-\mathrm{Co}(-0.68)-\mathrm{Sr}(-0.52)-\mathrm{Ba}(-051)-\mathrm{Li}
\end{aligned}
$$
$(-0.19)-\mathrm{CaCO}_{3}(-0.60)$.

This group is an antagonist of Assemblage IA(+). The presence of $\mathrm{CaCO}_{3}$, with a relatively high factor
Table 3. Stratigraphic distribution of factor scores (R-mode) for chemical elements of the upper Mesozoic sediments, Site 511, Falkland Plateau, Southwest Atlantic.

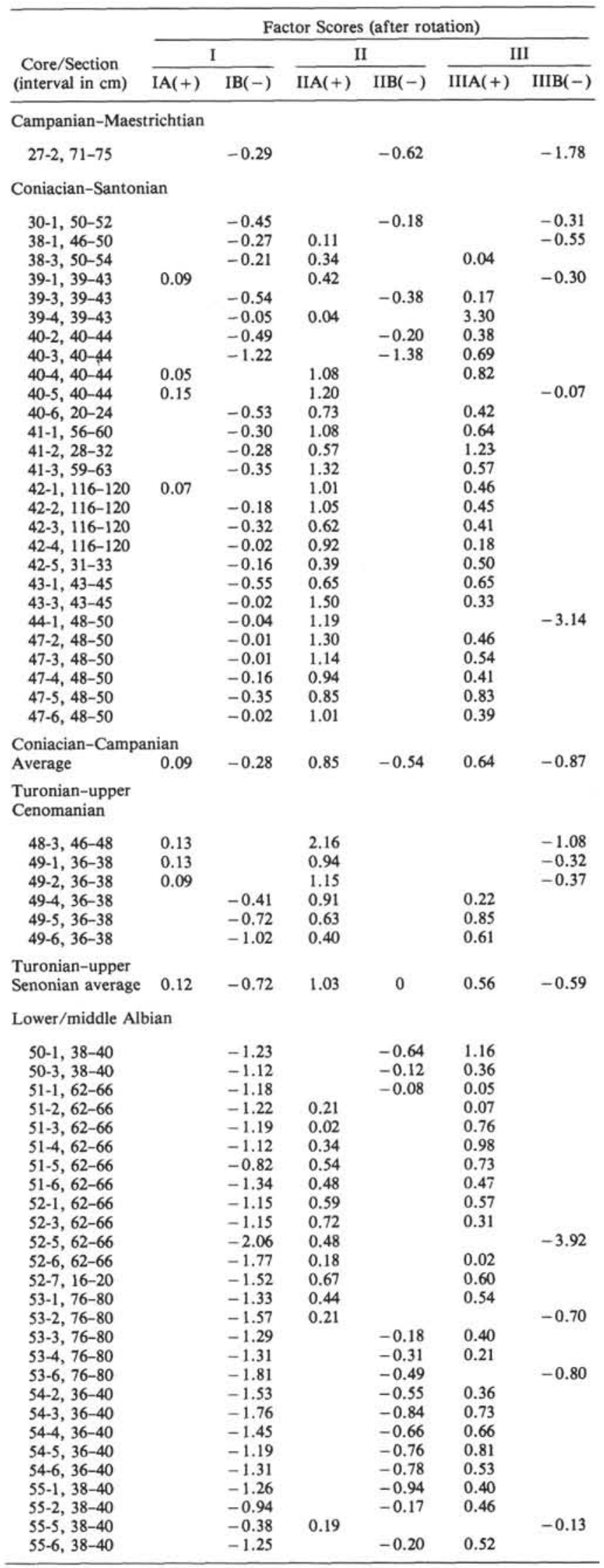


Table 3. (Continued).

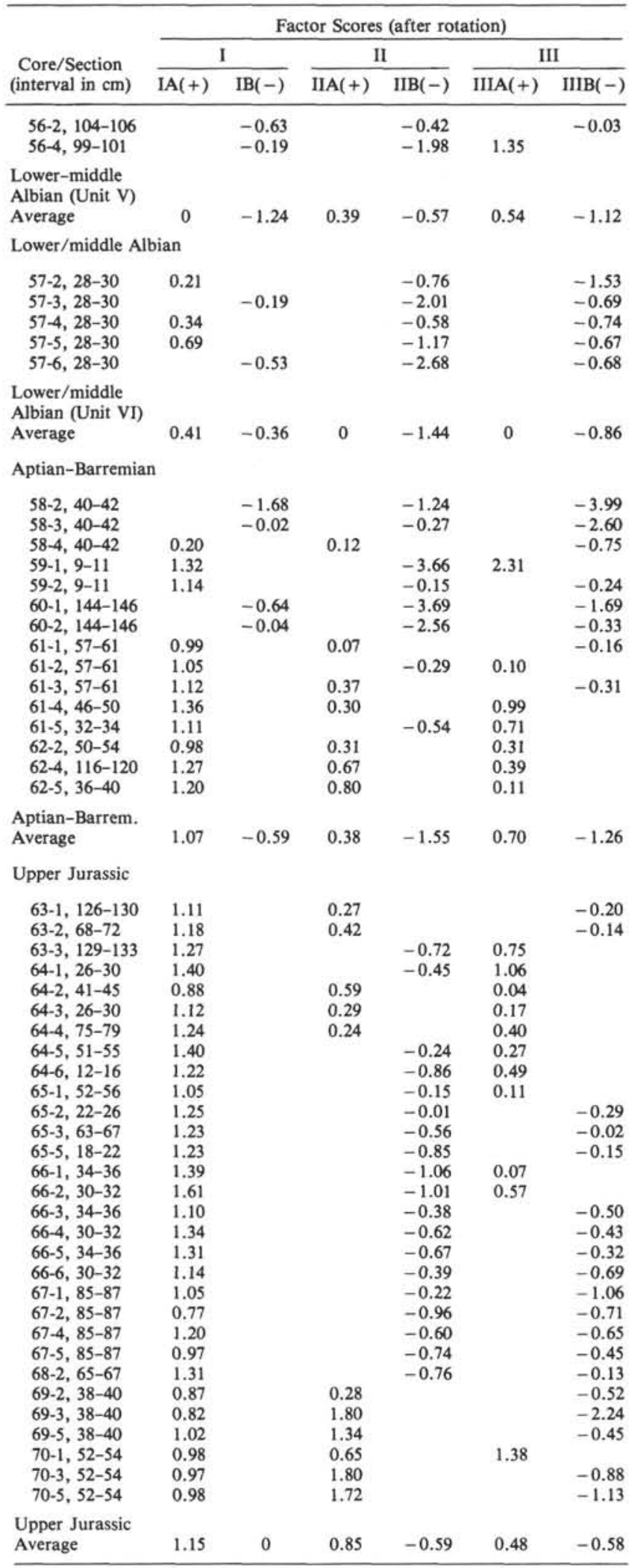

Note: Blanks indicate assemblage not present. loading, suggests that this group is represented by a carbonate phase containing elements in the form of an isomorphous admixture. The data show that the association can incorporate $\mathrm{Mn}$. The assemblage is best developed in lower-middle Albian (Unit V) and Turonianupper Cenomanian deposits (Fig. 1, Table 3). Worth noting is the biogenic mode of accumulation of most components of the cluster.

Assemblage IIA(+)

$\mathrm{Sc}(0.23)-\mathrm{Pb}(0.13)-\mathrm{Ga}(0.60)-\mathrm{Ti}(0.64)-\mathrm{Zr}(0.63)-$ $\mathrm{Li}(0.48)-\mathrm{Rb}(0.46)-\mathrm{Be}(0.38)$.

Dispersion: $15.82 \%$

The presence in this group of such characteristic elements as $\mathrm{Ti}, \mathrm{Zr}$, and $\mathrm{Ga}$ with relatively high factor loadings $(>0.60)$ suggests that the assemblage is represented by clastic material, along with clay minerals that developed after deposition. The presence of rare alkalis $(\mathrm{Li}$, $\mathrm{Rb}$ ) is indicative of mica; this finding is consistent with $\mathrm{X}$-ray diffraction data. This association is best developed in upper Cenomanian-Turonian and ConiacianSantonian deposits represented mostly by smectite-hydromicaceous clays-frequently zeolite of the heulandite type (see Table 3, Fig. 1).

Assemblage IIB(-)

$\mathrm{Nb}(-0.14)-\mathrm{Mo}(-34)-\mathrm{Cu}(-0.13)-\mathrm{Zn}(-0.50)-\mathrm{Ni}$ $(-0.52)-\mathrm{La}(-0.52)-\mathrm{CaCO}_{3}(-0.40)$.

The group is represented by an authigenic (postsedimentary) carbonate phase that includes elements with significant factor loadings $(>0.30)$ as isomorphous admixtures and, to a lesser extent, as adsorbed components (Mo, for instance).

The assemblage is most pronounced in the lower and middle Albian, Unit VI (factor score -1.44 ) and the Aptian-Barremian (-1.55), somewhat less so in Upper Jurassic deposits $(-0.59)$. Aggregates of microspherolitic patches $(0.007-0.02 \mathrm{~mm})$ of complex carbonates ( $\mathrm{Fe}, \mathrm{Mg}, \mathrm{Ca}, \mathrm{Mn}$ ) are visible under the microscope. The concentrated development of this group, very different from Upper Jurassic to Lower Cretaceous deposits, can be related to the extensive development of marine sedimentary environments in the Early Cretaceous.

\section{Assemblage IIIA(+)}

$\mathrm{Sc}(0.57)-\mathrm{Pb}(0.39)-\mathrm{Ga}(0.15)-\mathrm{Cu}(0.12)-\mathrm{Ti}(0.46)-$ $\mathrm{Zr}(0.27)-\mathrm{Cr}(0.16)-\mathrm{Sr}(0.56)-\mathrm{Ba}(0.37)-\mathrm{Y}(0.73)-\mathrm{Yb}$ $(0.68)-\mathrm{La}(0.22)-\mathrm{Rb}(0.29)-\mathrm{CaCO}_{3}(0.43)$

Dispersion: $9.25 \%$

The composition of this assemblage, its distribution within the section, and data on the mineral composition of the sediments suggest that it is related to at least two major phases: (1) volcanoclastic matter of basic composition transformed into clay, mostly smectitic material; the major element of this volcanogenic phase is Ti. (2) Carbonate developed during diagenesis/epigenesis after elements from the basic volcanoclastic material had dispersed into the silicate material. Figures 3,4 , and 5 show that the relatively high values of $\mathrm{Ti} / \mathrm{Zr}$ correspond to intervals when basaltoid volcanoclastics were accu- 

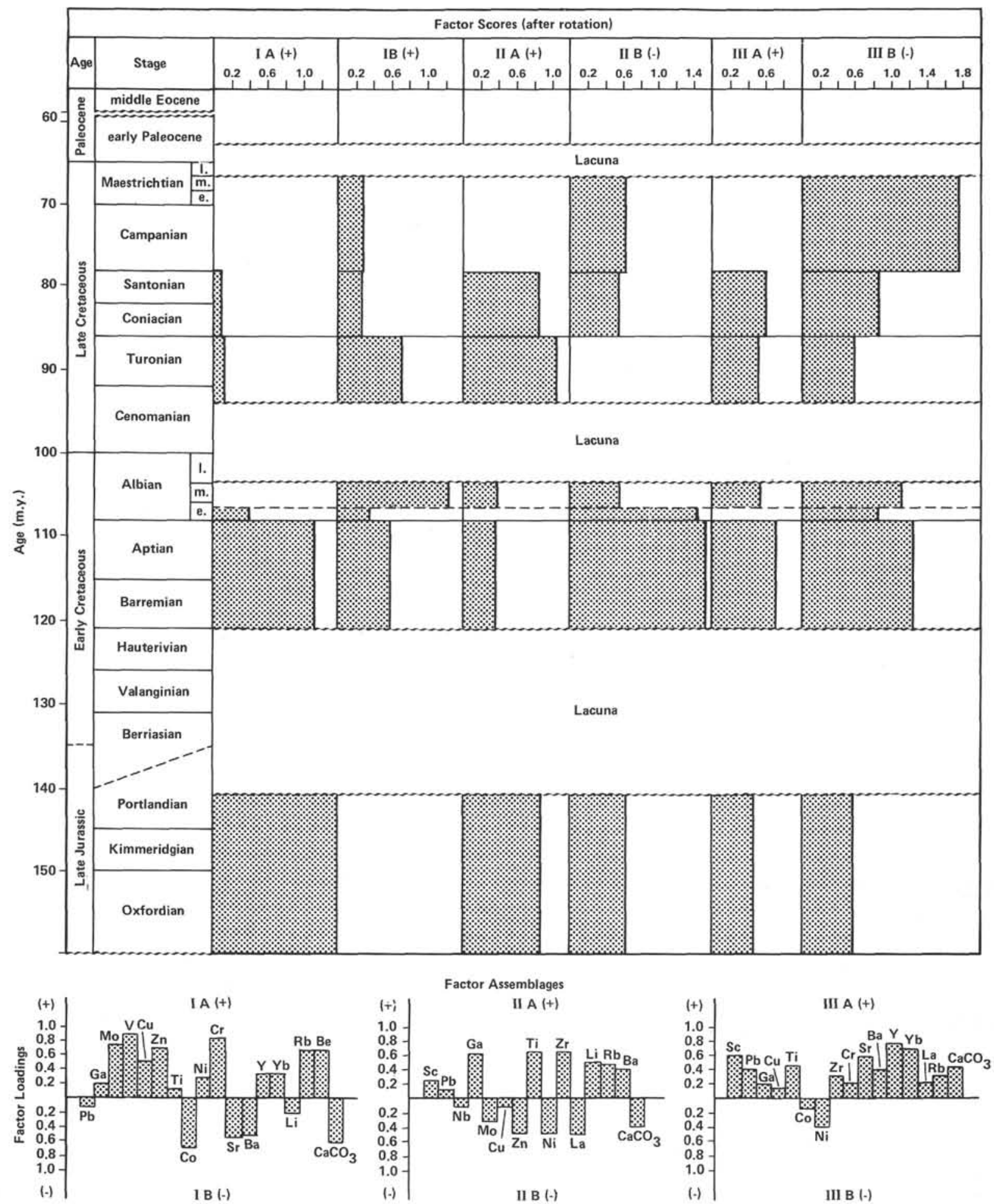

Figure 1. Distribution of average factor scores (R-mode) for paragenetic assemblages of trace and rare elements in upper Mesozoic sequences, Site 511, Falkland Plateau, Southwest Atlantic.

mulating. High factor scores are recorded in the same intervals for this assemblage (see Table 3 ).

\section{Assemblage IIIB(-) .}

$\mathrm{Co}(-17)-\mathrm{Ni}(0.40)$. This group is antagonistic to Assemblage IIIA(+). Relatively high factor scores (see Table 3) are observed mostly in Upper Jurassic, Barre-
mian-Aptian, lower and middle Albian (Unit VI and to a lesser extent Unit V) sediments and sporadically in higher horizons (upper part of the Turonian-upper Cenomanian, see Table 3). Ni and Co make up part of sulphide patches and $\mathrm{Fe}$ hydroxides. The association is clearly diagenetic, a product of postsedimentary concentration of dispersed metals. 


\section{DISTRIBUTION OF THE INDICATOR RATIOS OF ELEMENT El/Zr}

Elemental ratios are given in various papers that assess the geochemical parameters of sedimentation, the role of biological activity, hydrogenous deposition, hydrothermal inflow, supply of volcanoclastic components, terrigenous, glacial, and eolian constituents, and the products of authigenic mineral formation (Angino, 1968; Angino and Andrews, 1968; Chester, 1965; El Wakeel and Riley, 1961; Goldberg and Arrhenius, 1958; Turekian, 1968). For a ratio of elements to characterize well a geochemical process, one needs a relatively inert element that is rather evenly distributed in the phases under study. $\mathrm{Zr}$ is such an element under conditions of sediment lithogenesis. The $\mathrm{Zr}$ content in basalts and granites rich in $\mathrm{Ca}$ is $140 \mathrm{ppm}$. Similar values are recorded for clay rocks of the earth's crust (160) and deep sea clayey sediments (150; see Table 4; Turekian and Wedepohl, 1961). The data obtained by other authors differ only insignificantly from these values. Analysis of the distribution of such ratios makes it possible to compare lithologically different and heterofacial deposits.

\section{Ti/Zr (Figs. 2-5; Table 4)}

\section{The Geochemical Significance of the $\mathrm{Ti} / \mathrm{Zr}$ Ratio}

Goldberg and Arrhenius (1958), referring to earlier studies of the Atlantic carried out by Correns, showed that relatively high Ti concentrations in Pacific Ocean sediments are related mostly to the presence of basaltic volcanoclastic material. The concentration of $\mathrm{Ti}$ in clays

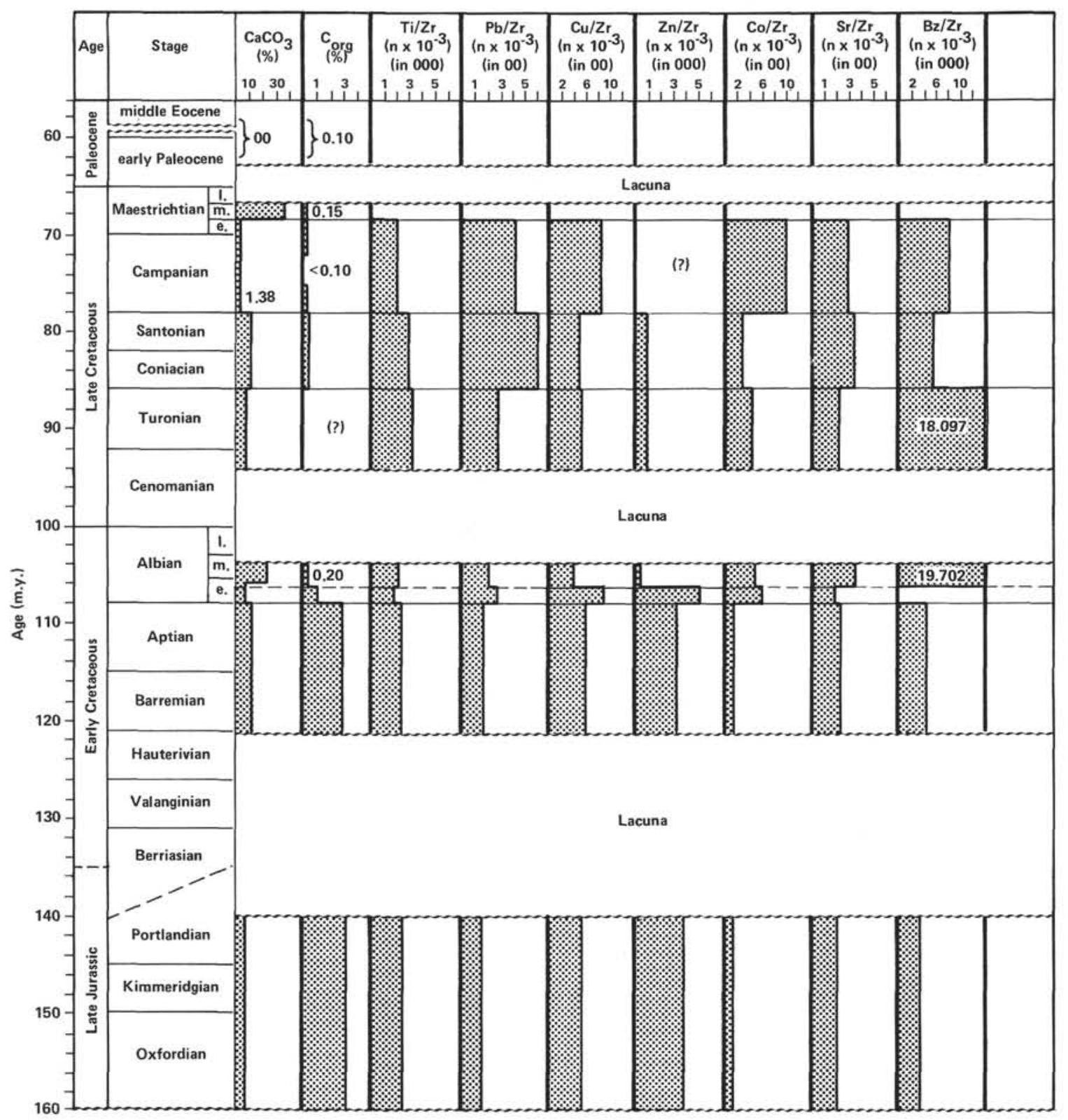

Figure 2. Distribution of average $\mathrm{CaCO}_{3}$ and $\mathrm{C}_{\text {org }}$ contents and average values of $\mathrm{Ti} / \mathrm{Zr}, \mathrm{Pb} / \mathrm{Zr}, \mathrm{Cu} / \mathrm{Zr}, \mathrm{Zn} / \mathrm{Zr}, \mathrm{Co} / \mathrm{Zr}$, $\mathrm{Sr} / \mathrm{Zr}$, and $\mathrm{Ba} / \mathrm{Zr}$ within upper Mesozoic sediments, Site 511 , Falkland Plateau, Southwest Atlantic. 


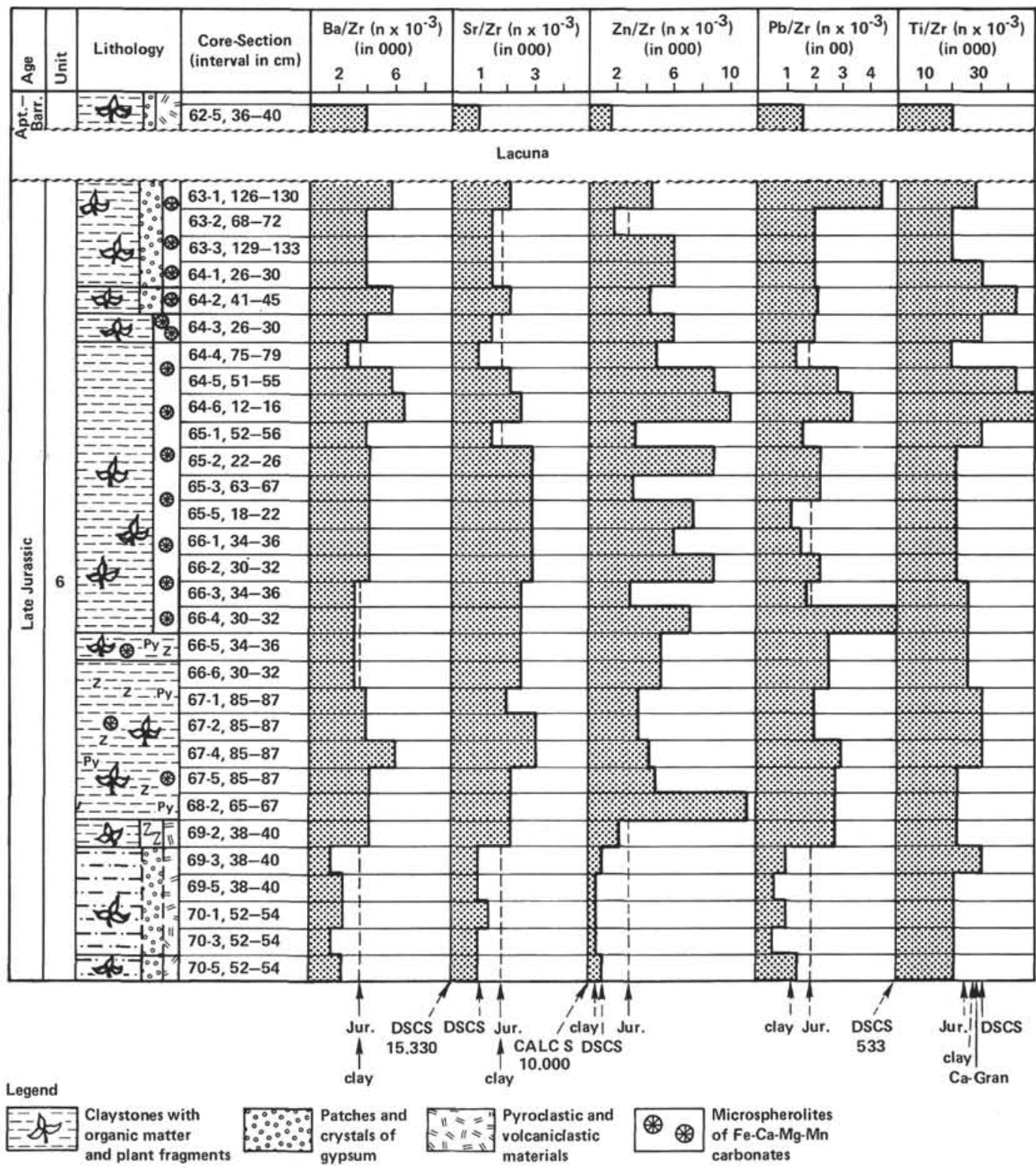

Figure 3. Distribution of $\mathrm{Ba} / \mathrm{Zr}, \mathrm{Sr} / \mathrm{Zr}, \mathrm{Zn} / \mathrm{Zr}, \mathrm{Pb} / \mathrm{Zr}$, and $\mathrm{Ti} / \mathrm{Zr}$ in Upper Jurassic sediments, Hole 511 , Cores 63-70 (556-632 m subbottom; Unit VI) Falkland Plateau, Southwest Atlantic. Dashed lines represent average ratios of elements for Upper Jurassic deposits (Jur); clays (clay, Turekian and Wedepohl, 1961); deep sea clayey sediments (DSCS; Turekian and Wedepohl, 1961); deep sea carbonate sediments (CALC S; Turekian and Wedepohl, 1961); and Ca-rich granite (Ca-Gran; Turekian and Wedepohl, 1961).

and deep sea clayey sediments $-4600 \mathrm{ppm}$, or $\mathrm{Ti} / \mathrm{Zr}$ $30,670 \times 10^{-3}$ (Turekian and Wedepohl, 1961)-is a critical value above which the occurrence of basaltoid material can be considered probable. This value is somewhat higher than the average content of $\mathrm{Ti}$ in Atlantic sediments-3100 ppm (Emelyanov, 1974). This has been repeatedly mentioned by many researchers as a feature resulting from a relatively high continental runoff.

\section{Distribution of $\mathrm{Ti} / \mathrm{Zr}$}

\section{Average Values (Fig. 2)}

From Upper Jurassic through middle Albian sediments $\mathrm{Ti} / \mathrm{Zr}$ values gradually decrease from $25,000 \times$
$10^{-3}$ to $21,277 \times 10^{-3}$. This suggests a significant input of decomposition products of continental sialic material and of medium/acid volcanoclastics. From the end of the Cenomanian to the Santonian, higher values of $\mathrm{Ti} /$ $\mathrm{Zr}$ (to $32,258 \times 10^{-3}$ ) testify to an increase in basaltoid volcanoclastics. This conclusion agrees with data on the mineral composition of sediments presented in other chapters of these Reports. On the whole, average values of the $\mathrm{Ti} / \mathrm{Zr}$ ratio for the major geochronological intervals in the Falkland Plateau region reveal that fine silty and clay sediment products derived from continental decomposition predominate (see Table 4). The data on upper Cenozoic deposits (DSDP Site 329; Tarney and Donnellan, 1977) show that in the interval from Oligo- 
TRACE ELEMENT GEOCHEMICAL HISTORY

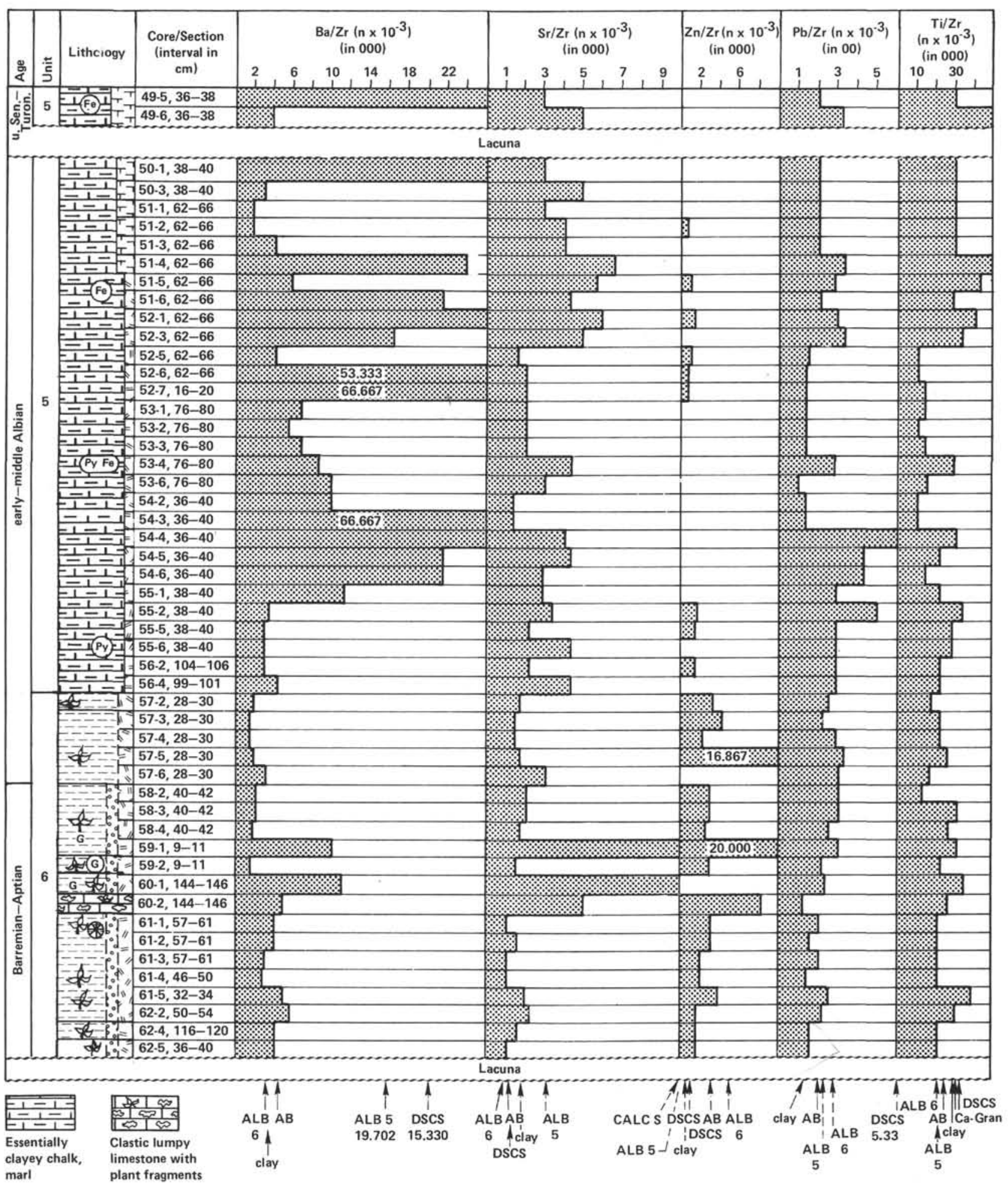

Figure 4. Distribution of $\mathrm{Ba} / \mathrm{Zr}, \mathrm{Sr} / \mathrm{Zr}, \mathrm{Zn} / \mathrm{Zr}, \mathrm{Pb} / \mathrm{Zr}$, and $\mathrm{Ti} / \mathrm{Zr}$ ratios in Lower Cretaceous sediments, Hole 511 , Cores 58-50 (432-556 m sub-bottom; Units V and VI Falkland Plateau, Southwest Atlantic. Arrows indicate average ratios of elements for lower-middle Albian sediments, Unit VI (ALB 6) and Unit V (ALB 5), average Aptian-Barremian sediments (AB), CLAY, DSCS, CALC S. (For explanations of other symbols see Fig. 3.)

cene to Holocene the average values of $\mathrm{Ti} / \mathrm{Zr}$ did not exceed $11,261 \times 10^{-3}$. This may indicate a relatively high silty sandy content in the product of continental runoff (Table 4).

Average figures, however, frequently flatten out sharply contrasting values that signal interesting geo- chemical phenomena within the geochronological intervals under study.

\section{Upper Jurassic (Fig. 3)}

These deposits are characterized by a pronounced tendency toward an increasing $\mathrm{Ti} / \mathrm{Zr}$ ratio in the upper 


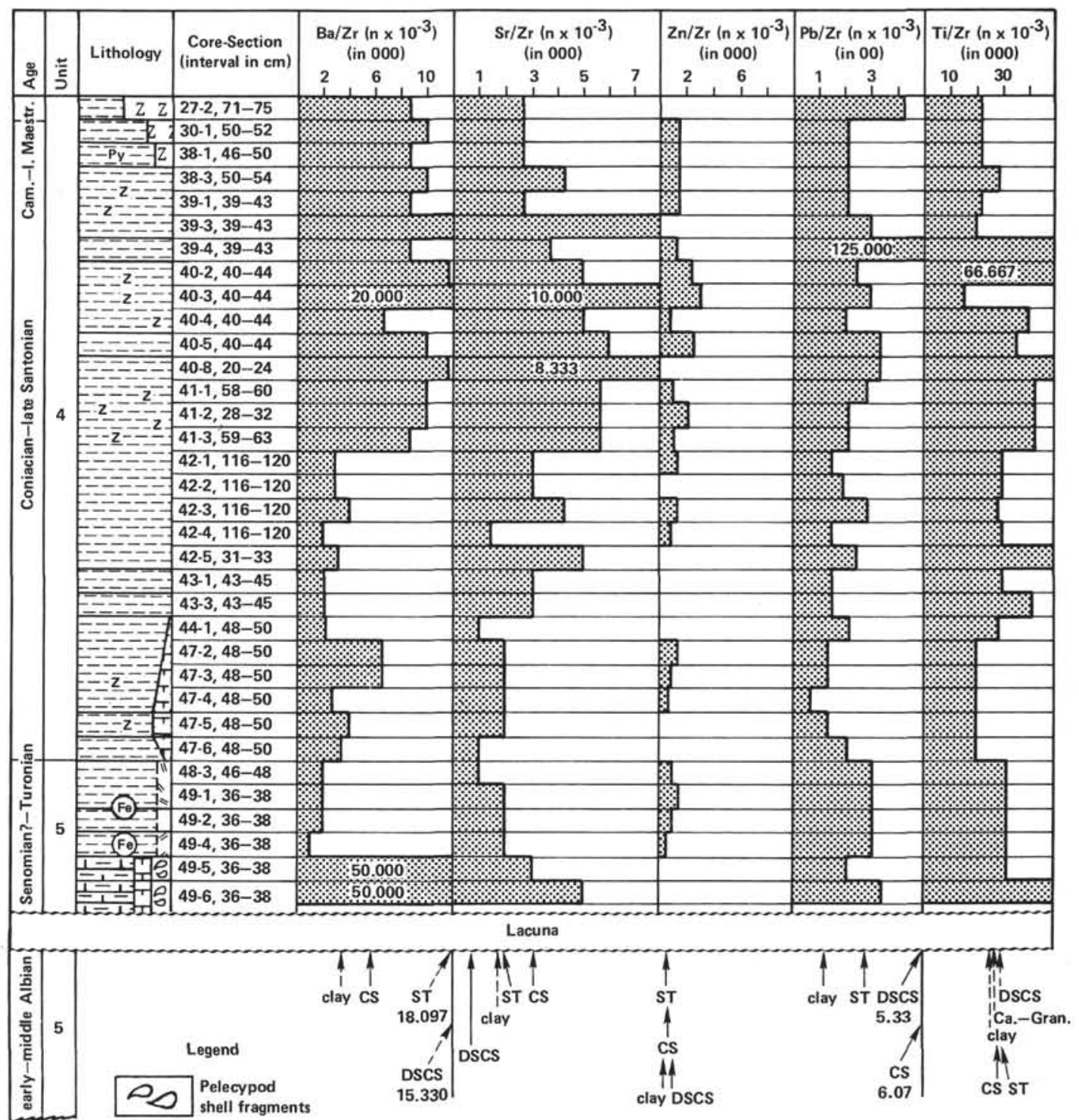

Figure 5. Distribution of $\mathrm{Ba} / \mathrm{Sr}, \mathrm{Sr} / \mathrm{Zr}, \mathrm{Zn} / \mathrm{Zr}, \mathrm{Pb} / \mathrm{Zr}$, and $\mathrm{Ti} / \mathrm{Zr}$ ratios in Upper Cretaceous sediments, Hole 511 , Cores 28-49 (sub-bottom depth 223.5-432.5 m; Units IV and V) Falkland Plateau, Southwest Atlantic. Arrows indicate average ratios of elements for average Coniacian-Santonian sediments (CS), average upper Senonian-Turonian sediments (ST), CLAY, DSCS, Ca-GRAN. (For explanations of other symbols see Fig. 3.)

part of the interval (higher than Sample 511-65-1, 52-56 $\mathrm{cm})$. This can be related both to an increase in the relative amounts of basaltoid hyalopelitic material and to an increase of residual titanium components near the boundary of a large erosional gap. (Hauterivian-Portlandian, about 20 m.y.)

\section{Barremian/Aptian to Albian (Fig. 4)}

A relatively monotonous distribution of $\mathrm{Ti} / \mathrm{Zr}$ slightly deviating from the average values, is observed.

\section{Second Half of the Lower-Middle Albian (Fig. 4)}

In the interval from Samples 511-50-1, 38-40 to 511$53-3,62-66 \mathrm{~cm}, \mathrm{Ti} / \mathrm{Zr}$ reaches $50,000 \times 10^{-3}$, a high value that is explained by the presence of basaltoid volcanoclastic material and the appreciable enrichment of sediments with residual titanium in finely dispersed min- erals near the boundary, with a considerable stratigraphic hiatus ( 10-12 m.y., late Albian-Cenomanian).

\section{Upper Cenomanian/Turonian-Upper Santonian (Fig. 5)}

There are two intervals with relatively high $\mathrm{Ti} / \mathrm{Zr}$ values: (1) A basal layer (Sample 511-49-6, 36-38 cm) resting directly above the erosional gap just noted $(\mathrm{Ti} /$

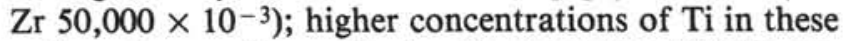
sediments are of a residual, relic character. (2) The upper part of the Coniacian-upper Santonian (Samples $511-39-4,39-43 \mathrm{~cm}$ to $511-42-5,31-33$ ), characterized by $\mathrm{Ti} / \mathrm{Zr}$ values up to $66,667 \times 10^{-3}$. These sediments have a higher content of fine silty-pelitic, basaltic volcanoclastic material strongly zeolitized.

Thus, the distribution of the $\mathrm{Ti} / \mathrm{Zr}$ values reveals both residual accumulations near erosional contacts and 
Table 4. Average contents of trace elements and element/Zr ratios for the main stratigraphic subdivisions of upper Mesozoic sediments, Sites 329 and 511, Falkland Plateau, Southwest Atlantic.

\begin{tabular}{|c|c|c|c|c|c|c|c|c|c|c|c|c|c|c|c|c|c|c|c|}
\hline \multirow{2}{*}{$\begin{array}{l}\text { Sediment } \\
\text { Lithology }\end{array}$} & \multirow[b]{2}{*}{ Age } & \multicolumn{11}{|c|}{ Contents $^{\mathrm{a}}$} & \multicolumn{6}{|c|}{ Ratios $\left(\times 10^{-3}\right)$} & \multirow{2}{*}{$\begin{array}{l}\text { Data } \\
\text { Source }\end{array}$} \\
\hline & & $\mathrm{Pb}$ & $\mathrm{Ti}$ & $\mathrm{Zr}$ & $\mathrm{Cu}$ & $\mathrm{Zn}$ & Co & $\mathrm{Ni}$ & Sr & $\mathrm{Ba}$ & $\mathrm{Yb}$ & $\mathrm{La}$ & $\mathrm{Ti} / \mathrm{Zr}$ & $\mathrm{Ba} / \mathrm{Zr}$ & $\mathrm{Cu} / \mathrm{Zr}$ & $\mathrm{Zn} / \mathrm{Zr}$ & $\mathrm{Sr} / \mathrm{Zr}$ & $\mathrm{Pb} / \mathrm{Zr}$ & \\
\hline $\begin{array}{l}\text { Silty sand, enriched in siliceous sedi- } \\
\text { ment, ooze }\end{array}$ & Holocene & 11 & $0.145 \%$ & 165 & 176 & 131 & - & 29 & 126 & 516 & - & 14 & 8788 & 3127 & 1067 & 794 & 764 & 67 & DSDP Site 329 \\
\hline Nannofossil diatomaceous oozes & Pleistocene-upper Pliocene & 10 & $0.125 \%$ & 112 & 180 & 80 & - & 23 & 491 & 545 & - & 12 & 11,261 & 4866 & 1607 & 714 & 4384 & 89 & DSDP Site 329 \\
\hline Diatomaceous nannofossil chalk & $\begin{array}{l}\text { upper Miocene } \\
\text { middle-unner Miocene }\end{array}$ & 3 & $0.077 \%$ & 85 & 185 & 64 & - & 25 & 739 & 413 & - & 7 & 9059 & 4859 & 2176 & 753 & 8694 & 91 & DSDP Site 329 \\
\hline Diatomaceous nannofossil chalk & & 5 & $0.068 \%$ & 80 & 189 & 56 & - & 18 & 777 & 431 & - & 5 & 8500 & 5388 & 2363 & 700 & 9713 & 63 & DSDP Site 329 \\
\hline Diatomaceous nannofossil chalk & lower-midddle Miocene & 8 & $0.062 \%$ & 77 & 152 & 33 & - & 10 & 1205 & 997 & - & 8 & 8052 & 12,948 & 1974 & 429 & 15,649 & 104 & DSDP Site 329 \\
\hline Diatomaceous nannofossil chalk & Oligocene & 5 & $0.068 \%$ & 43 & 154 & 43 & - & 26 & 1120 & 458 & - & 8 & 8293 & 5585 & 1878 & 524 & 13,659 & 61 & DSDP Site 329 \\
\hline Claystones, zeolitic claystones & Campanian-Maestrichtian & 30 & 1500 & 70 & 60 & - & 70 & 150 & 200 & 600 & 2 & 40 & 21,429 & 8571 & 857 & - & 2857 & 429 & DSDP Site 511 \\
\hline Claystones, zeolitic clays & Coniacian-Santonian & 54 & 2674 & 89 & 41 & 17 & 23 & 46 & 306 & 554 & 3 & 41 & 30,045 & 6225 & 461 & 865 & 3438 & 607 & DSDP Site 511 \\
\hline $\begin{array}{l}\text { Claystones, marls, muddy nannofossil } \\
\text { chalks }\end{array}$ & $\begin{array}{l}\text { Turonian-upper } \\
\text { Cenomanian }\end{array}$ & 27 & 3000 & 93 & 52 & 70 & 40 & 57 & 217 & 1683 & 3 & 40 & 32,258 & 18,097 & 559 & 753 & 2333 & 290 & DSDP Site 511 \\
\hline $\begin{array}{l}\text { Claystones, maris, muddy nannofossil } \\
\text { chalks }\end{array}$ & $\begin{array}{l}\text { lower-middle Albian } \\
\text { (Unit V) }\end{array}$ & 21 & 2000 & 94 & 34 & 28 & 46 & 58 & 291 & 1852 & 3 & 37 & 21,277 & 19,702 & 362 & 298 & 3096 & 223 & DSDP Site $\$ 11$ \\
\hline $\begin{array}{l}\text { "Black shales," mudstones, nannofossil } \\
\text { mudstones }\end{array}$ & $\begin{array}{l}\text { lower-middle Albian } \\
\text { (Unit VI) }\end{array}$ & 17 & 1260 & 62 & 58 & 330 & 380 & 250 & 110 & 190 & 3 & 50 & 20,323 & 3065 & 935 & 5323 & 1774 & 274 & DSDP Site 511 \\
\hline $\begin{array}{l}\text { "Black shales," mudstones, nannofossil } \\
\text { mudstones }\end{array}$ & Aptian-Barremian & 15 & 1807 & 78 & 49 & 263 & 11 & 81 & 170 & 337 & 3 & 35 & 23,167 & 4321 & 628 & 3372 & 2179 & 192 & DSDP Site 511 \\
\hline $\begin{array}{l}\text { "Black shales," mudstones, nannofossil } \\
\text { mudstones }\end{array}$ & Upper Jurassic & 16 & 2150 & 86 & 46 & 345 & 15 & 79 & 157 & 320 & 3 & 27 & 25,000 & 3721 & 535 & 4012 & 1826 & 186 & DSDP Site 511 \\
\hline \multicolumn{20}{|l|}{ Average values } \\
\hline Clays (AVG) & & 20 & 4600 & 160 & 45 & 95 & 19 & 68 & 300 & 580 & 2.6 & 92 & 28,750 & 3620 & 281 & 594 & 1875 & 125 & Turekian and Wedepohl, 1961 \\
\hline Deep sea carbonate sediments (AVG) & & 9 & 770 & 20 & 30 & 35 & 7 & 30 & 2000 & 190 & 1.5 & 10 & 6820 & - & - & 73 & 91 & 32 & Turekian and Wedepohl, 1961 \\
\hline Deep sea clayey sediments (AVG) & & 80 & 4600 & 150 & 250 & 165 & 74 & 225 & 180 & 2300 & 1.5 & 115 & 3850 & 9500 & 1500 & 1750 & 100,000 & 450 & Turekian and Wedepohl, 1961 \\
\hline Basalt (AVG) & & 6 & $1.38 \%$ & 140 & 87 & 105 & 48 & 13 & 465 & 330 & 2.1 & 15 & 30,670 & 15,330 & 1666 & 1100 & 1200 & 533 & Turekian and Wedepohl, 1961 \\
\hline $\mathrm{Ca}=$ rich granite $(\mathrm{AVG})$ & & 15 & $0.34 \%$ & 140 & 87 & 105 & 7 & 15 & 440 & 420 & 3.5 & 45 & 98,570 & 2360 & 621 & 621 & 3321 & 43 & Turekian and Wedepohl, 1961 \\
\hline \multicolumn{20}{|c|}{ 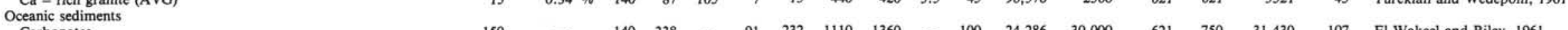 } \\
\hline Carbonates & & 150 & - & 140 & 338 & - & 91 & 232 & 1110 & 1360 & - & 100 & 24,286 & 30,000 & 621 & 750 & 31,430 & 107 & El Wakeel and Riley, 1961 \\
\hline Clayey & & 175 & - & 126 & 400 & - & 100 & 300 & 450 & 2000 & - & 90 & - & 9714 & 2414 & - & 7929 & 1072 & El Wakeel and Riley, 1961 \\
\hline Siliceous & & 180 & - & 170 & 370 & - & 200 & 330 & 230 & 105 & - & 80 & - & 15,873 & 3175 & - & 3571 & 1389 & El Wakeel and Riley, 1961 \\
\hline Pelagic clay sediments, Pacific Ocean & & 150 & - & 180 & 740 & - & 160 & 320 & 710 & 3900 & - & 140 & - & 6176 & 2176 & - & 1353 & 1059 & Goldberg and Arrhenius, 1958 \\
\hline Deep sea clays, Atlantic Ocean & & 52 & - & - & 115 & 129 & 39 & 79 & - & - & - & - & - & 21,667 & 4111 & - & 3944 & 833 & Turekian and Imbrie, 1966 \\
\hline $\begin{array}{l}\text { Marine glacial sediments (AVG), } \\
\text { Weddell Sea }\end{array}$ & & - & 2600 & 238 & 70 & - & 20 & 46 & - & - & - & - & 10,924 & - & - & - & - & - & Angino, 1966 \\
\hline
\end{tabular}

Note: Contents and ratios of elements in the sediments from Hole 329, after Tarney and Donnellan, 1976. Contents and ratios of elements in sediments from Hole 511 calculated from the data in Table 1 . Values for element contents in ppm unless otherwise indicated. 
intervals of accumulation of basaltic volcanoclastics. It is notable that manifestations of basaltic explosive volcanism shown in the $\mathrm{Ti} / \mathrm{Zr}$ ratios preceded, as a rule, large erosional gaps. The latter can result from tectonic activity in the areas adjacent the Falkland Plateau.

\section{$\mathrm{Ba} / \mathrm{Zr}$ (Figs. 2-5; Table 4)}

\section{Geochemical Significance of the $\mathrm{Ba} / \mathrm{Zr}$ Ratio}

The average content of $\mathrm{Ba}$ in suspended river matter (400 ppm; Gurvich et al., 1978), is somewhat lower than the $\mathrm{Ba}$ concentration in clays $(580 \mathrm{ppm}$ or $\mathrm{Ba} / \mathrm{Zr} 3620 \times$ $10^{-3}$; Turekian and Wedepohl, 1961). Maximum concentrations of $\mathrm{Ba}$ can be observed in deposits related to high biological productivity and in hydrothermal metalliferous sediments (Chester, 1965; El Wakeel and Riley, 1961; Goldberg and Arrhenius, 1958; Turekian, 1968; Turekian and Imbrie, 1966). In deep sea clay sediments the concentration of $\mathrm{Ba}$ is $2300 \mathrm{ppm}$ or $(\mathrm{Ba} / \mathrm{Zr} 15,330 \times$ $10^{-3}$; Turekian and Wedepohl, 1961). This value is tentatively accepted as critical; when it is higher, the causes of the relatively high $\mathrm{Ba}$ content in the sediment should be considered.

\section{Distribution of $\mathrm{Ba} / \mathrm{Zr}$}

\section{Average values (Fig. 2)}

Three stages identified in the distribution of average $\mathrm{Ba}$ values in the upper Mesozoic section are (1) Upper Jurassic-lower/middle Albian (Unit VI; 3065-4321 × $10^{-3}$ ); where the range of values remains within the values established by typical suspended river matter and relatively shallow water terrigenous sediments. (2) Lower-middle Albian (Unit V, upper Cenomanian-Turonian; $\left.18,097-19,702 \times 10^{-3}\right)$, high values representative of essentially clay nanno-micritic sediments affected by such factors as relatively high biological productivity, volcanogenic emanations, and authigenic concentration of $\mathrm{Ba}$ by hydroxides of $\mathrm{Fe}$ or $\mathrm{Mn}$. (3) Coniacian-Santonian-Campanian-Maestrichtian; $6252-8571 \times 10^{-3}$, values similar to the indices for the late Cenozoic (see Table 4), and characteristic of relatively deep water, open-ocean environments.

Again, average values level out extremes that are of interest for understanding the geochemical history of the basin.

\section{Upper Jurassic (Fig. 3)}

This interval is characterized by accumulation of sediments with a relatively monotonous distribution of $\mathrm{Ba} / \mathrm{Zr}$, deviating only slightly from the average values.

\section{Barremian-Aptian-Albian (Unit VI; Fig. 4)}

The distribution of $\mathrm{Ba} / \mathrm{Zr}$ differs only insignificantly from that shown for Upper Jurassic sediments.

\section{Lower-Middle Albian (Unit V; Fig. 4)}

Clay nanno-micritic sediments accumulated, with an appreciable admixture of basic volcanoclastic material and abnormally high values of $\mathrm{Ba} / \mathrm{Zr}$ (to $66,667 \times 10^{-3}$ ). Basaltic volcanoclastics were recorded in the upper part of this interval with high $\mathrm{Ba} / \mathrm{Zr}$ values (Samples 511$51-4,62-66 \mathrm{~cm}$ to $511-55-1,38-40 \mathrm{~cm}$ ), as was noted in considering $\mathrm{Ti} / \mathrm{Zr}$ ratios. In interpreting the $\mathrm{Ba} / \mathrm{Zr}$ distribution, it should be borne in mind that in Recent diatomaceous sediments of the near Antarctic zone of high biological productivity, the $\mathrm{Ba} / \mathrm{Zr}$ ratio reaches $\sim 30,000 \times 10^{-3}$, somewhat higher than a similar ratio for carbonate varieties of metalliferous sediments (Gurvich et al., 1978). Along with the Fe- and Mn-hydroxides dispersed in the ground mass of the clay nannomicritic sediments are authigenic collectors (concentrators) of $\mathrm{Ba}$, initially volcanogenic and later transformed by biological concentration.

\section{Upper Cenomanian-Turonian-Upper Santonian (Fig. 5)}

Two intervals of high $\mathrm{Ba} / \mathrm{Zr}$ values are distinguished: (1) basal (Upper Santonian-Turonian) resting directly under a rather extensive erosional hiatus $(\mathrm{Ba} / \mathrm{Zr} 50,000$ $\left.\times 10^{-3}\right)$. The residual, relic nature of barite accumulations is obvious in this case. (2) A zone of relatively high $\mathrm{Ba} / \mathrm{Zr}$ values (up to $20,000 \times 10^{-3}$ ) distinctly distinguished in the Coniacian-Upper Santonian (Samples $511-30-1,50-52 \mathrm{~cm}$ to $511-41-3,59-63)$. As already mentioned, observation by microscope and high values of $\mathrm{Ti} / \mathrm{Zr}$ (Fig. 5) testify to a significant role of hyalopelite-silty basaltic matter and of possible products of hydrothermal exhalations.

\section{Sr/Zr (Figs. 2-5; Table 4)}

\section{Geochemical Significance of the $\mathrm{Sr} / \mathrm{Zr}$ ratio}

In marine sediments the biogenic carbonate components are the main carriers of Sr. To a lesser extent this function is assumed by clay matter, $\mathrm{Fe}$ - and $\mathrm{Mn}$ hydroxides, and authigenic phosphates (Chester, 1965; El Wakeel and Riley, 1961; Goldberg and Arrhenius, 1958). Concentrations of $\mathrm{Sr}$ in deep sea carbonate sediments $\left(2000 \mathrm{ppm} ; \mathrm{Sr} / \mathrm{Zr} 100,000 \times 10^{-3}\right)$ and in deep sea clay sediments $\left(180 \mathrm{ppm}\right.$; $\left.\mathrm{Sr} / \mathrm{Zr} 1200 \times 10^{-3}\right)$ are considered critical values (Turekian and Wedepohl, 1961). An Sr concentration of $2000 \mathrm{ppm}$ is regarded by most researchers (Chester, 1965) as abnormally high, peculiar to Recent sediments of the equatorial zone of high biological productivity of the Atlantic Ocean.

\section{Distribution of $\mathrm{Sr} / \mathrm{Zr}$}

\section{Average Values (Fig. 2)}

The following intervals have distinctive distribution of $\mathrm{Sr} / \mathrm{Zr}$ average values: (1) the Upper Jurassic-lowermiddle Albian (accumulation time of Unit VI; $\mathrm{Sr} / \mathrm{Zr}$ $1774-2179 \times 10^{-3}$ ); these values are close to the $\mathrm{Sr} / \mathrm{Zr}$ ratios for continental clays $\left(1875 \times 10^{-3}\right)$ and shallowwater marine terrigenous sediments. (2) Lower-middle Albian (Unit V)-Campanian-Maestrichtian; during this interval the $\mathrm{Sr} / \mathrm{Zr}$ ratios varied slightly from $2333-$ $3438 \times 10^{-3}$, corresponding to values characteristic of carbonate-clay sediments of the open ocean. Worth noting are Oligocene-lower-middle Miocene sediments (see Table 5; Sr/Zr 13,659-15,649 × 10-3. An outburst 
of biological productivity then occurred as a result of the northward penetration of Antarctic waters rich in nutrient components in conjunction with the opening of the Drake Passage.

\section{Upper Jurassic (Fig. 3)}

Sediments are characterized by a relatively even distribution of $\mathrm{Sr} / \mathrm{Zr}$, slightly differing from the values earlier considered average.

\section{Barremian-Aptian-Albian (Unit VI)}

The distribution of $\mathrm{Sr} / \mathrm{Zr}$ was close to that observed for Upper Jurassic sediments (see Fig. 4).

\section{Lower-Middle Albian (Fig. 4)}

In this interval, the same general patterns of distribution hold for $\mathrm{Sr} / \mathrm{Zr}, \mathrm{Ba} / \mathrm{Zr}$, and $\mathrm{Ti} / \mathrm{Zr}$ : an abrupt increase in the values of the ratios in the upper part of the interval as the explosive-hydrothermal activity of basaltoid volcanism intensified. In the process, such elements as $\mathrm{Ba}$ and $\mathrm{Sr}$ could be appreciably transformed by biological factors. Worth noting is the outburst of volcanism that preceded the erosional hiatus (late AlbianCenomanian, about $12 \mathrm{~m} . \mathrm{y}$.) and was related to tectonic activity.

\section{Upper Cenomanian-Turonian-Coniacian-Upper Santonian (Fig. 5)}

$\mathrm{Sr} / \mathrm{Zr}$ is distributed with the same regularity as $\mathrm{Ba} / \mathrm{Zr}$ and, in general, $\mathrm{Ti} / \mathrm{Zr}$. This similarity is attributed to common causes: residual basal accumulations (Sample $511-49-6,36-38 \mathrm{~cm}$ ) and effects of biological transformations of volcanogenic products (Samples 511-38-3, $50-54 \mathrm{~cm}$ to $511-41-3,59-63 \mathrm{~cm})$.

\section{$\mathrm{Pb} / \mathrm{Zr}$ (Figs. 2-5; Table 4)}

\section{Geochemical Significance of the $\mathrm{Pb} / \mathrm{Zr}$ Ratio}

An important feature of $\mathrm{Pb}$ in sedimentary processes is its tendency toward accumulation in authigenic phases from sea water, mostly in Mn and Fe hydroxides and in organic matter but to a lesser extent in clayey components. The result is a greater $\mathrm{Pb}$ enrichment of pelagic than of shallow-sea sediments. This difference is more obvious for pelagic sediments in oceanic basins where continental runoff predominates (the Atlantic, for instance, where $\mathrm{Pb}$ is $52 \mathrm{ppm}, \mathrm{Pb} / \mathrm{Zr}$ is $347 \times 10^{-3}$; Turekian and Imbrie, 1966) and volcanogenic-hydrothermal sources exist (the Pacific Ocean, for instance, where $\mathrm{Pb}$ is $150 \mathrm{ppm}$ and $\mathrm{Pb} / \mathrm{Zr}$ is $1000 \times 10^{-3}$; Goldberg and Arrhenius, 1958). In coastal sea sediments the $\mathrm{Pb}$ content does not as a rule exceed the concentration of this element in clays (see Table 4: $\mathrm{Pb} / \mathrm{Zr}, 125 \times 10^{-3}$; Chester, 1965; El Wakeel and Riley, 1961; Goldberg and Arrhenius, 1958; Turekian and Imbrie, 1966). These $\mathrm{Pb} / \mathrm{Zr}$ values enable one to understand the genesis of the deposits when they are analyzed in the context of data on lithology, mineralogy, and geochemistry of the major and trace elements.

\section{Distribution of $\mathbf{P b} / \mathrm{Zr}$}

\section{Average Values (Fig. 2)}

Average $\mathrm{Pb} / \mathrm{Zr}$ values may be subdivided into four main intervals:

1) Upper Jurassic-Barremian-Aptian: Sediments are characterized by $\mathrm{Pb} / \mathrm{Zr}$ values up to $192 \times 10^{-3}$, peculiar to shallow-water sea deposits.

2) Lower-middle Albian (Unit VI): Relatively higher values of $\mathrm{Pb} / \mathrm{Zr}\left(290 \times 10^{-3}\right)$ testify to deepening of the basin and an appreciable contribution of volcanogenic products.

3) Lower-middle Albian (Unit V)-late CenomanianTuronian: Average $\mathrm{Pb} / \mathrm{Zr}$ values approximate those characteristic of Recent pelagic sediments of the Atlantic $-290 \times 10^{-3}$.

4) Upper Coniacian-Santonian-Campanian-Maestrichtian: $\mathrm{Pb} / \mathrm{Zr}$ values increase to $607 \times 10^{-3}$. These data and data on the mineral composition of sediments indicate that volcanogenic exhalation components play an appreciable role.

In Tertiary sediments of this region (Site 329, DSDP Leg 36$), \mathrm{Pb} / \mathrm{Zr}$ values vary from $61 \times 10^{-3}$ (Oligocene) to $104 \times 10^{-3}$ (early/middle Miocene), testifying mostly to the accumulation of products of continental runoff that is considerably diluted by siliceous calcareous biogenic remains.

\section{Upper Jurassic (Fig. 3)}

Sediments are characterized by relatively even distribution of $\mathrm{Pb} / \mathrm{Zr}$, slightly deviating from average values; their genetic nature has already been discussed.

\section{Barremian-Aptian-Lower-middle Albian Unit VI (Fig. 4)}

Sediments show a clear tendency toward increasing $\mathrm{Pb} / \mathrm{Zr}$ values by the end of the interval, indicating an appreciable deepening of the basin, relatively marked patterns of marine sedimentation, and the presence of volcanogenic products. The gradual character of this transition is noteworthy.

\section{Lower-Middle Albian (Unit V)}

Higher values of $\mathrm{Pb} / \mathrm{Zr}$ prevail in the upper part of the interval. Approximately within the same limits, an increase of $\mathrm{Ba} / \mathrm{Zr}, \mathrm{Sr} / \mathrm{Zr}$, and particularly $\mathrm{Ti} / \mathrm{Zr}$ was mentioned. Volcanogenic processes played a significant role in such changes of sediment geochemistry along with the development of an open marine sedimentary regime.

\section{Upper Cenomanian-Turonian-Coniacian-Santonian (Fig. 5)}

The distribution of the $\mathrm{Pb} / \mathrm{Zr}$ values in this interval cannot be so clearly distinguished as that of $\mathrm{Ti} / \mathrm{Zr}$, $\mathrm{Ba} / \mathrm{Zr}$, and $\mathrm{Sr} / \mathrm{Zr}$ (upper half of the Coniacian-upper Santonian; Fig. 5). The noticeable changes in the geochemistry indicate both normal oceanic conditions and volcanic phenomena. 


\section{Zn/Zr (Figs. 2-5; Table 4)}

\section{Geochemical Significance of the $\mathrm{Zn} / \mathrm{Zr}$ Ratio}

The geochemical features of zinc in relation to the sedimentary process have been poorly studied. When river runoff enters a sedimentation basin, a considerable part of the suspended $\mathrm{Zn}$ (up to $70-90 \%$ total $\mathrm{Zn}$ ) is detrital and metallo-organic. Further distribution of $\mathrm{Zn}$ in a basin is controlled by hydrodynamic conditions. In the succession river-estuary-sea, the role of dissolved metallo-organic forms of $\mathrm{Zn}$ abruptly increases. Under open-ocean conditions the main factor controlling the distribution of $\mathrm{Zn}$ is the biological activity of plankton (Leinen and Stakes, 1979). The ratios of $\mathrm{Zn} / \mathrm{Zr}$ for clays $\left(594 \times 10^{-3}\right)$ and deep sea clay sediments $\left(1100 \times 10^{-3}\right)$ can be taken as critical values (Turekian and Wedepohl, 1961).

\section{Distribution of $\mathrm{Zn} / \mathrm{Zr}$}

\section{Average Values (Fig. 2)}

The average values of $\mathrm{Zn} / \mathrm{Zr}$ may be subdivided into three main intervals:

1) Upper Jurassic-lower-middle Albian (Unit VI): Sediments are characterized by abnormally high $\mathrm{Zn} / \mathrm{Zr}$ values: $3372-5323 \times 10^{-3}$. The intense accumulation of $\mathrm{Zn}$ in "black shales"' (Unit VI) is due to a relatively high content of humified organic matter (up to $3-5 \% \mathrm{C}_{\text {org }}$ ) and to a lesser extent of dispersed sulphides. Thus the accumulation of plant detritus and sapropelic, suspended, organic matter in the relatively shallow water sea basin of the Southwest proto-Atlantic controlled the accumulation of $\mathrm{Zn}$ as well as the subsequent diagenetic redistribution of this element.

2) Early/middle Albian (Unit V): Sediments are characterized by a sharp decrease in the average $\mathrm{Zn} / \mathrm{Zr}$ value $\left(298 \times 10^{-3}\right)$, compared to preceding deposits. Such a large change is related to the development of a normal marine, well-aerated sedimentary regime, in which the average $\mathrm{C}_{\text {org }}$ content in sediments decreased to $0.20 \%$, and the amount of nanno-micritic $\mathrm{CaCO}_{3}$ (the diluting material) increased to $28 \%$.

3) Upper Cenomanian-Turonian-Coniacian-Santonian. Average $\mathrm{Zn} / \mathrm{Zr}$ values $\left(753-865 \times 10^{-3}\right)$ in these sediments are rather close to the ratios in the middleupper Miocene-Holocene sediments (see Tarney and Donnellan, 1977, Table 5, DSDP Site 329). Taking into consideration the peculiarities of the geochemistry and mineral composition of sediments in this interval, we can state that $\mathrm{Zn}$ owes its accumulation mostly to biological transformation of dissolved forms supplied from the continental runoff and from endogenic sources.

\section{Upper Jurassic (Fig. 3)}

Sediments are characterized by an uneven distribution of $\mathrm{Zn} / \mathrm{Zr}$ that tends to increase upsection. The genetic interpretation has already been given.

\section{Barremian-Aptian-Lower/middle Albian (Unit VI; Fig. 4)}

Despite considerable fluctuations, $\mathrm{Zn} / \mathrm{Zr}$ values in these sediments tend to increase. Such an uneven distri- bution of $\mathrm{Zn} / \mathrm{Zr}$ is related, as already mentioned, to peculiarities in the occurrence of the organic matter that is the main carrier of $\mathrm{Zn}$.

\section{Lower-middle Albian (Unit V; Fig. 4)}

The $\mathrm{Zn} / \mathrm{Zr}$ values, rather unevenly distributed in the section, decrease in these sediments. Rather large values of $\mathrm{Zn} / \mathrm{Zr}$ are recorded in the upper part of the interval, which is characterized by high values of $\mathrm{Ti} / \mathrm{Zr}, \mathrm{Ba} / \mathrm{Zr}$, $\mathrm{Sr} / \mathrm{Zr}$, and $\mathrm{Pb} / \mathrm{Zr}$ that result from manifestations of basic volcanism. The factors causing the general decrease in $\mathrm{Zn} / \mathrm{Zr}$ in this interval have been described already.

\section{Upper Cenomanian-Turonian-Coniacian-upper Santonian (Fig. 5)}

$\mathrm{Zn} / \mathrm{Zr}$ is unevenly distributed but shows a tendency to increase in the upper Coniacian-upper Santonian. This interval (see Fig. 5) is also characterized by higher values of $\mathrm{Ti} / \mathrm{Zr}, \mathrm{Ba} / \mathrm{Zr}, \mathrm{Sr} / \mathrm{Zr}$, and $\mathrm{Pb} / \mathrm{Zr}$ that reveal intensified basaltoid volcanism.

\section{DISCUSSION: GEOCHEMICAL HISTORY OF LATE MESOZOIC SEDIMENTATION}

DSDP Site 511 is located in the basin province of the Falkland Plateau, approximately $10 \mathrm{~km}$ south of DSDP Site 330 , Leg 36 . The oldest deposits, occurring on weathered granitoids of the continental basement, are Middle-Upper Jurassic sediments (Barker, Dalziel, et al., 1977). The location of Site 511 was chosen to study the history of sedimentation in the late Mesozoic and Cenozoic, the role of erosional phenomena, and the general development of the Southwest Atlantic basin. Even though the geochemical aspects of Cenozoic sedimentation of this region have been elucidated (Tarney and Donnellan, 1977), there is no information on the geochemistry of upper Mesozoic sediments.

The main stages and phases of the geochemical history of sedimentation in the late Mesozoic are:

\section{Stage 1: Late-Middle Jurassic-Early Cretaceous (160-106 m.y.); Sedimentation in a Relatively Shallow Water Stagnant Basin}

\section{Late Jurassic (140-160 m.y.)}

During the Late Jurassic (and Middle Jurassic according to some DSDP Leg 36 reports) relatively shallow water (shelf), mostly clayey sediments with a small admixture of silty glassy particles of medium-acid composition (up to $10 \%$ ) accumulated. The presence of dispersed sapropel-like organic matter and plant fragments (up to $7 \%$ ), pyrite-marcasite patches (to 7\%) and quartz is notable, and epigenetic rosettes and gypsum crystals are also present (see Fig. 3.). The clay matter is represented mostly by mixed-layer Na-montmorillonite with a small amount of micaceous packets, hydromica, and an admixture of chlorite and kaolinite. Sediments accumulated in a basin characterized by pronounced stagnation and an oxygen-free regime in bottom waters (Barker, Dalziel, et al., 1977; Ludwig, Krasheninnikov, et al., 1980; Thompson, 1977). A characteristic geochemical feature of the sediments is the accumulation of 
dispersed organic matter (average $\mathrm{C}_{\text {org }} 3.26 \%$ ), closely related to $\mathrm{Zn}, \mathrm{Cu}, \mathrm{Cr}, \mathrm{Rb}$, and $\mathrm{Be}$ (Assemblage $\mathrm{IA}[+$ ]; see Tables 2, 3, and Fig. 1). These are organometallic compounds. The concentration of other elements does not exceed, as a rule, the average contents in clays (see Table 4 and Figs. 1-5).

\section{Late Jurassic (Portlandian)-Early Cretaceous (Hauter- ivian) (142-121 m.y.); Hiatus in Sedimentation}

This extensive hiatus is associated with the initial break-up of the Gondwanaland supercontinent and the embryonic stage in the formation of the South Atlantic (Barker, Dalziel et al., 1977; Ludwig, Krasheninnikov, et al., 1980).

\section{Early Cretaceous (Barremian-Aptian-Early-Middle Albian (Unit VI) (121-106? m.y.)}

During this time sediments similar to those of Late Jurassic times accumulated. However, deepening of the basin manifested itself in the accumulation of relatively smaller amounts of organic matter and an increase in the carbonate content of the sediments (see Fig. 2), whereas the regime of oxygen-poor bottom waters and restricted water exchange persisted in the basin. These insignificant changes in sedimentation conditions were represented geochemically by a smaller accumulation of components related to organic matter: $\mathrm{V}, \mathrm{Zn}, \mathrm{Cu}, \mathrm{Cr}$, (Assemblage IA $[+]$; see Figs. 1, 2, Tables 2-4) and diagenetic concentrations of $\mathrm{Zn}, \mathrm{Ni}, \mathrm{La}$, and perhaps Mo in the carbonate phase (Assemblage IIB[-], see Figs. 1, 2, Tables 2-4).

\section{Stage 2: Early-Middle Albian (Unit V)-Middle Maestrichtian (106?-66.6 m.y.); Sedimentation in an Open Oceanic Basin}

\section{Early-Middle Albian (Unit V), 106?-104 m.y.}

In the second half of the early-middle Albian sedimentation conditions changed significantly. During this time there accumulated variegated (later red), mostly clayey nannofossil oozes represented by nanno-micritic (average $\mathrm{CaCO}_{3}=28.03 \%$ ) clay matter (up to $50-70 \%$ ), dispersed Fe-hydroxides (up to 5-7\%), and an admixture of medium to basic volcanoclastic material (up to $10 \%$ ). The clay matter is composed of a range of mixedlayer montmorillonite-mica, hydromica, and an admixture of kaolinite.

According to Sliter (Barker, Dalziel et al., 1977) who studied benthic foraminifers, the depth of the basin does not exceed values typical of the shelf (100-400 m). The geochemical signature of this time interval is reflected in its biogenic components- $\mathrm{Ba}, \mathrm{Sr}, \mathrm{CaCO}_{3}$, and Co (diagenetically bound into a carbonate form) (Assemblage IB [-]; see Figs. 1, 2, Tables 2-5). Worth noting in the second half of this interval are the abruptly increased values of $\mathrm{Ti} / \mathrm{Zr}$, interpreted as evidence of an outburst of basaltoid volcanism associated with tectonic activity before a sedimentation hiatus. This conclusion was confirmed by microscope observations. Rather high concentrations of $\mathrm{Pb}, \mathrm{Zn}, \mathrm{Ba}, \mathrm{Sr}$ and other metals are related to this volcanic activity (see Fig. 4).

\section{Late Albian-Late Cenomanian (104-94? m.y.); Hiatus in Sedimentation}

This hiatus is related to the ongoing expansion and deepening of the basin and to activation of currents between the eastern and western parts of the Antarctic in the Late Cretaceous and Cenozoic that is confirmed by paleomagnetic data (Barker, Dalziel, et al., 1977).

\section{Late Cenomanian-Turonian (94?-86 m.y.)}

This time interval is characterized by the accumulation of mostly clay sediments (mixed-layer montmorillonite-mica, hydromica, and chlorite admixtures), frequently with appreciable amounts of nanno-micrite, remains of foraminifers (up to $30 \%$ ), dispersed Fe-hydroxides, admixtures of basic volcanoclastic materials, and fragments of pelecypods (up to $20 \%$ ). The rate of sedimentation is extremely low (below $3.2 \mathrm{~mm} / 10^{3} \mathrm{y}$.). These data enable one to regard these sediments as residual products preserved despite the strong bottom currents active since the preceding hiatus.

Extension and deepening of the open oceanic basin continued. Sedimentation was characterized by intense accumulation of components such as $\mathrm{Ti}, \mathrm{Zr}$, and the related rare alkalis $\mathrm{Cs}, \mathrm{Li}$, and $\mathrm{Rb}$ (Assemblage IIA[+]; see Tables 2, 3, Figs. 1-5) that indicate the residual nature of the clay sediments. $\mathrm{Ni}$ and $\mathrm{La}$, incorporated into a postsedimentary carbonate phase (Assemblage IIB [-], see Tables 2, 3, and Fig. 1), were recognized in lesser amounts. High values of $\mathrm{Ti} / \mathrm{Zr}$ and $\mathrm{Ba} / \mathrm{Zr}, \mathrm{Sr} / \mathrm{Zr}$ as products of residual, relic enrichment (Fig. 5) in the basal layer of the sediments mark the boundary of the hiatus.

\section{Coniacian-Santonian (86-78 m.y.)}

This time interval witnessed a rather intense accumulation $\left(23.7 \mathrm{~mm} / 10^{-3} \mathrm{y}^{-1}\right)$ of mostly clay sediments represented by montmorillonite with small amounts of mica interlayers (up to 10-20\%), hydromica, chlorite admixtures, and sometimes kaolinite, quartz, and feldspar. In the later sediments there are appreciable amounts of zeolites (from the heulandite group), formed after finely dispersed basic volcanoclastics. Sedimentation took place in a relatively deep water (not less than 2000 $\mathrm{m}$ ), open ocean basin below the carbonate compensation depth, during active circulation of meridional currents (Barker, Dalziel, et al., 1977). The sediments are characterized by the accumulation of rather high amounts of $\mathrm{Ti}$ and $\mathrm{Zr}$, the bound rare alkalis $\mathrm{Li}$ and $\mathrm{Rb}$ (Assemblage IIA[+]; see Tables 2, 3, and Fig. 1), lesser amounts of diagenetic carbonate phases of $\mathrm{Ni}, \mathrm{Zn}, \mathrm{La}$ (Assemblage IIB [-]), and sulphide and oxide phases of $\mathrm{Fe}$ with an admixture of Ni, Co (Assemblage IIIB[-]), Of special interest are accumulations of fine basaltoid volcanoclastic material, partly transformed diagenetically into carbonates recognized as groups of $\mathrm{Sc}, \mathrm{Pb}, \mathrm{Ti}$, $\mathrm{Sr}, \mathrm{Ba}, \mathrm{Y}, \mathrm{Yb}$, and $\mathrm{CaCO}_{3}$ (Assemblage IIIA $[+]$ ) in sediments of the later half of the interval. Such intense enrichment of these sediments with $\mathrm{Ti}, \mathrm{Ba}, \mathrm{Sr}$, and other elements in connection of the volcanic outburst is evident in increased values of the $\mathrm{Ti} / \mathrm{Zr}, \mathrm{Ba} / \mathrm{Zr}, \mathrm{Sr} / \mathrm{Zr}$, and other ratios (see Fig. 5). 


\section{Campanian-Early Maestrichtian (78.0-68.3 m.y.)}

Clay sediments with an admixture of fine volcanoclastics accumulated during this interval and were subsequently transformed into essentially zeolitic minerals (up to $70 \%$ ). The clay matter is represented by mixedlayer montmorillonite-mica, hydromica, and zeolite from the heulandite group. The sedimentation rate was rather low: $1.5 \mathrm{~mm} / 10^{3} \mathrm{y}$. This can be interpreted as evidence of the beginning of intense bottom currents preceding the development of a large global hiatus at the Mesozoic/Cenozoic boundary.

Data on the geochemistry of these sediments are rather fragmentary. Chemically, they can be considered to resemble the deposits accumulated at the end of the preceding interval.

\section{Middle Maestrichtian (68.3-66.4 m.y.)}

Mostly clay sediments accumulated, with clastic glauconite (up to $30 \%$ ) and frequently with an admixture of nanno-micrite and basic volcanoclastics (up to $10 \%$ ), variously zeolitized. The clay matter is represented by mixed-layer montmorillonite-mica, hydromica, and zeolite from the heulandite group. Sedimentation took place in deep-water, open-ocean environments at rather low rates: $7.3 \mathrm{~mm} / 10^{3} \mathrm{y}$.

\section{Late Maestrichtian-Late Eocene (66.4-57? m.y.): Hiatus in Sedimentation}

The paleoceanographic nature of this almost global hiatus has been reviewed in numerous works (for instance, Barker, Dalziel, et al., 1977; Ciesielski and Wise, 1977; Ludwig, Krasheninnikov et al., 1980; Thiede and van Andel, 1977;).

\section{CONCLUSION}

The section of late Mesozoic sediments penetrated at DSDP Site 511 in the basin province of the Falkland Plateau is crucial for studying the early stages of the geochemical history of sedimentation in the Southwest Atlantic Ocean.

The major phases of development are delineated in this chapter through study of the distribution of paragenetic assemblages of trace and rare elements in the section; these are revealed by factor analysis (R-, Q-mode), peculiarities of the element/Zr ratios, and interpretations of the data in the context of information on the mineralogy, lithology, and geology of the region.

\section{Stage 1: Late-Middle Jurassic-Early Cretaceous (160-106? m.y.)}

Relatively shallow water (shelf), mostly clay sediments accumulated at that time, with appreciable amounts of dispersed sapropel-like organic matter and plant fragments, pyrite, marcasite, quartz, volcanic glass, and epigenetic crystals of gypsum. Sedimentation occurred in a markedly stagnant environment, with oxygen-poor bottom water layers. Sediments are characterized by higher concentrations of $\mathrm{V}, \mathrm{Zn}, \mathrm{Cu}, \mathrm{Cr}, \mathrm{Rb}$, and $\mathrm{Be}$ associated with dispersed organic matter ( $\mathrm{C}_{\text {org }}$ up to $3.26 \%$ ).
In the Early Cretaceous, following a significant erosional hiatus, the basin tended to deepen and expand. Sediments chemically similar to those of Late Jurassic times accumulated here. These were distinguished, however, by diagenetic concentrations of $\mathrm{Zn}, \mathrm{Ni}$, and $\mathrm{La}$ in the carbonate phase.

\section{Stage 2: Early-middle Albian (Unit V)-Middle Maestrichtian (106?-66.6 m.y.)}

This stage is characterized by sedimentation in an open ocean basin, normally oxygenated and with a pronounced tendency toward expansion and deepening.

During the early-middle Albian biogenic components accumulated $\left(\mathrm{Ba}, \mathrm{Sr}\right.$, and $\left.\mathrm{CaCO}_{3}\right)$. At the end of this interval $\mathrm{Ti} / \mathrm{Zr}$ values increase, testifying to an outburst of basaltoid volcanism related to tectonic activity before the erosional hiatus (late Albian-late Cenomanian).

At the end of the late Cenomanian-Turonian mostly clay sediments accumulated, with rather high $\mathrm{Ti}$ and $\mathrm{Zr}$ and related rare alkalis $(\mathrm{Li}, \mathrm{Rb})$ that reveal the residual nature of the clays. During the Coniacian-Santonian, clay sediments accumulated, characterized by higher concentrations of $\mathrm{Ti}, \mathrm{Zr}, \mathrm{Li}, \mathrm{Rb}$, diagenetic carbonate phases of $\mathrm{Ni}, \mathrm{Zn}, \mathrm{La}$, sulphides, and $\mathrm{Fe}$-oxides with admixtures of $\mathrm{Ni}$ and $\mathrm{Co}$. The latter half of this interval shows the accumulation of fine basaltoid volcanoclastic material diagenetically altered by zeolitization and carbonitization and enriched with $\mathrm{Sc}, \mathrm{Pb}, \mathrm{Ti}, \mathrm{Sr}, \mathrm{Ba}, \mathrm{Y}$, and $\mathrm{Yb}$. Chemically similar sediments accumulated during the Campanian-middle Maestrichtian.

Activation of currents preceding a large global erosional hiatus at the Mesozoic/Cenozoic boundary is reflected in both the lower rates of sedimentation and the residual higher concentrations of $\mathrm{Ti}, \mathrm{Zr}, \mathrm{Ba}, \mathrm{Sr}$, and others.

\section{ACKNOWLEDGMENTS}

I am grateful to colleagues of the Geological Institute of the U.S.S.R. Academy of Sciences: D. A. Kazimirov, N. I. Kartoshkina, and N. Y. Vlasova, for their help in computer processing of the analytical data, recalculation, and presentation of the results; B. A. Sakharov and T. G. Eliseeva, for X-ray structural analysis and assistance in interpretation of the data obtained; V. A. Krasheninnikov, for the study materials and consultation on stratigraphy; E. I. Pyatigorskaya, O. D. Smirnova, and O. P. Kachan for help in graphic work, and G. N. Surovtseva and I. G. Sheremet for translation of the paper.

Critical review of the paper and comments by N. G. Brodskaya and A. G. Kossovskaya improved the work.

\section{REFERENCES}

Angino, E. E., 1966. Geochemistry of Antarctic pelagic sediments. Geochim. Cosmochim. Acta, 30:939-960.

Angino, E. E., and Andrews, R. S., 1968. Trace elements chemistry, heavy minerals and sediment statistics of Weddell Sea sediments. J. Sediment. Petrol., 38(no. 2):634-642.

Chester, R., 1965. Elemental geochemistry of marine sediments. In Riley, J. P., and Skirrow, G. (Eds.), Chemical Oceanography: New York and London (Academic Press), pp. 23-80.

Ciesielski, P., and Wise, S. W., 1977. Geologic history of the Maurice Ewing Bank of the Falkland Plateau (South West Atlantic Sector of the Southern Ocean) based on piston and drill cores. Mar. Geol., 25:175-207.

Davis, J. C., 1973. Statistic and Data Analysis in Geology: New York (John Wiley and Sons). 
El Wakeel, S. K., and Riley, J. P., 1961. Chemical and mineralogical studies of deep-sea sediments. Geochim. Cosmochim. Acta, 25: 110-146.

Emelyanov, E. M., 1974. Titanium in sediments of the Atlantic Ocean. Geochimia, No. 4:610-615.

Geological Society of London, 1974. Phanerozoic time scale. Geol. Soc. London, Quart. J., 120:260-262.

Goldberg, E. D., and Arrhenius, G. O. S., 1958. Chemistry of Pacific pelagic sediments. Geochim. Cosmochim. Acta, 13:153-212.

Gurvich, E. G., Bogdanov, Y. A., Lisitzin, A. P., 1978. Barium behavior in recent sedimentation in the Pacific Ocean. Geochimia, No. 3:359-374.

Hardenbol, J., and Berggren, W. A., 1978. A new Paleogene numerical time scale. Am. Assoc. Pet. Geol. Stud. Geol., 6:213-234.

Harman, H. H., 1967. Modern Factor Analysis: Chicago, Ill. (University of Chicago Press).

Larson, R. L., and Hilde, T. W. C., 1975. A reversal time scale of magnetic reversals for the Early Cretaceous and Late Jurassic. $J$. Geophys. Res., 80:2586-2594.

Leinen, M., and Stakes, D., 1979. Metal accumulation rates in the central equatorial Pacific during Cenozoic time. Bull. Geol. Soc. Am., Pt. I, 90:357-375.

Ludwig, W. J., Krasheninnikov, V. A., Basov, I. A., Bayer, U., Bloemendal, J., Bornhold, B., Ciesielski, P., Goldstein, E. H., Robert, Ch., Usher, J. L., Salloway, J. C., von der Dick, H., Weaver, F. M., Wise, Jr., S.W. 1980. Tertiary and Cretaceous paleoenvironments in the southwest Atlantic Ocean: Preliminary results of Deep Sea Drilling Project, Leg 71. Bull. Geol. Soc. Am., Pt. 1, 91(No. 11):655-664.

Nicholls, G. D., 1967. Trace elements in sediments: An assessment of their possible utility as depth indicators. Mar. Geol., 5:539-555.

Shipboard Scientific Party, with Harris W. and Sliter W. V., 1977. Evolution of the southwestern Atlantic Ocean basin: Results of
Leg 36, Deep Sea Drilling Project. In Barker, P. F., Dalziel, I. W. D., et al., Init. Repts. DSDP, 36: Washington (U.S. Govt. Printing Office), 993-1014.

Tarney, J., and Donnellan, N. C. B., 1977. Minor element geochemistry of sediments at Site 328, Falkland Outer Basin and Site 329, Falkland Plateau, Leg 36, Deep Sea Drilling Project. In Barker, P. F., Dalziel, I. W. D., et al., Init. Repts. DSDP, 36, Washington (U.S. Govt. Printing Office), 929-939.

Thiede, J., van Andel, Tj. H., 1977. The paleoenvironment of anaerobic sediments in Late Mesozoic South Atlantic Ocean. Earth Planet. Sci. Lett., 33:301-309.

Thompson, R. W., 1977. Mesozoic sedimentation on the eastern Falkland Plateau. In Barker, P. F., Dalziel, I. W. D., et al., Init. Repts. DSDP, 36: Washington (U.S. Govt. Printing Office), 877-891.

Turekian, K. K., 1968. Deep Sea deposition of barium, cobalt and silver. Geochim. Cosmochim. Acta, 32:603-612.

Turekian, K. K., and Imbrie, J., 1966. The distribution of trace elements in deep sea sediments of the Atlantic Ocean. Earth Planet. Sci. Lett., 1:161-168.

Turekian, K. K., and Wedepohl, K. H., 1961. Distribution of the elements in some major units of the Earth's crust. Bull. Geol. Soc. Am., 72(No. 2):175-192.

Van Eysinga, F. W. B., comp., 1975. Geological Time Table, (3rd Ed.): Amsterdam (Elsevier).

van Hinte, J. E., 1976. A Cretaceous time scale. Bull. Am. Pet. Geol., 60(No. 4):498-516.

Varentsov, I. M., 1980. Metalliferous sediments of the North Atlantic (geochemistry; peculiar features of their formation). Marine Geology, Sedimentology, Sedimentary Petrography, and Geology of the Ocean. Internat. Geol. Cong., Leningrad 26th Sess., Repts. Soviet Geologists,: Leningrad (Nedra), pp. 29-42. 